\title{
Zilyetliğin Havalesinde Üçüncü Kişinin Hukukî Durumu ve Kiralananın Devrinde Kiracının Hukukî Durumu ile Karşılaştırılması
}

\author{
Yasin Alperen Karaşahin ${ }^{*}$ ()
}

Öz

Türk ve İsviçre hukuklarında, zilyetliğin havalesi, özel bir hukukî ilişkiye dayanarak eşyaya zilyet olan üçüncü kişinin rızası aranmaksızın, devreden ile devralan arasında yapılan bir sözleşme ile devralana dolaylı zilyetlik kazandırılması imkânını yaratmaktadır. Üçüncü kişinin rızası olmaksızın yapılan bu işlemin onun menfaatlerini ihlâl etmemesi için kanunda bazı düzenlemeler yer almaktadır. Türk Medenî Kanunu'nun 979. maddesinin 2. fikrasına göre, zilyetliğin havalesi, üçüncü kişiye devreden tarafindan bildirilmesinden önce üçüncü kişi açısından hüküm ve sonuç doğurmamaktadır. Bu hüküm ile öngörülen nisbî etkisizlik, üçüncü kişiye yapılan bildirim ile sona ermektedir; dolayısıyla üçüncü kişiye geçici bir koruma sağlamaktadır. Türk Medenî Kanunu’nun 979. maddesinin 3. fikrasına göre, üçüncü kişi devredene karşı ileri sürebildiği savunmalara dayanarak eşyayı devralana teslimden kaçınabilir. Türk ve İsviçre doktrinlerinde hâkim olan görüşün aksine, bu hüküm aynî hakka dayanan savunmaların yanında şahsî (nisbî) hakka dayanan savunmaların da devralana ileri sürülmesine imkân vermektedir. Söz konusu düzenleme, hükmün sözünde açıklık olmasa da, sadece taşınırlar üzerinde devralana aynî hak kazandırılması için zilyetliğin devri gereken hâllerde uygulanmalıdır. İsviçre doktrininde savunulan yeni görüşün aksine, zilyetliğin havalesinin bildirimi üzerine, üçüncü kişi ile devreden arasındaki ilişkide devredenin yerini devralanın alması söz konusu değildir. Türk ve İsviçre hukuklarında, kira sözleşmesinin kurulmasından sonra kiralananın devri durumunda, devreden yerine devralanın kiraya veren olması yönünde açık bir düzenleme yer almaktadır. Bu düzenleme kiralananın taşınır veya taşınmaz olması açısından bir fark getirmemektedir. Bu makalede savunulan görüşe göre, kira sözleşmesine dair özel hüküm olmasaydı bile, kiralanan taşınırın mülkiyetinin zilyetliğin havalesi ile devri durumunda üçüncü kişi (kiracı) kiralananı kira süresinin sonuna kadar teslimden kaçınabilirdi. Bu nedenle, taşınır kiraları açısından kiralananın devrine dair özel düzenleme, kiracının irade serbestîsine ölçüsüz bir müdahale teşkil etmektedir.

\author{
Anahtar Kelimeler \\ Zilyetliğin Havalesi, Şahsî (Nisbî) Hak, Kira Sözleşmesi, Taşınır, Savunma
}

Legal Position of Third Party in Transfer of Indirect Possession by an Agreement between Transferor and Transferee Compared to Lessee in Case of Transfer of Leased Property

\begin{abstract}
$^{+}$
In Turkish and Swiss law, if a bailee (third party) is in possession based on a legal relationship with the bailor, the bailor (transferor) can transfer the indirect (constructive) possession by an agreement with the transferee without the consent of the third-party bailee. The Turkish Civil Code (CC) - like the Swiss Civil Code - contains some provisions intended to prevent any negative effect from such an agreement on the interests of the third party. First, the transfer of indirect possession by agreement between transferor and transferee has no legal effect on the third party until that party is notified by the transferor (Article 979/II of Turkish Civil Code [CC]). This period of ineffectiveness ends upon notice to the
\end{abstract}

+ The concepts of English personal property law do not correspond to the concepts of Turkish, Swiss and German laws. Nevertheless, in order to make the abstract and the extended summary more easily understandable to readers from common law jurisdictions, the equivalent concepts of English personal property law are used in addition to the concepts of Turkish, Swiss and German laws. For the concepts of English and German laws, see Andreas Rahmatian, 'A Comparison of German Moveable Property Law and English Personal Property Law' (2008) 3 J Comp L 197.

* Sorumlu Yazar: Yasin Alperen Karaşahin (Dr. Öğr. Üyesi), Koç Üniversitesi, Hukuk Fakültesi, Medenî Hukuk Ana Bilim Dalı, İstanbul, Türkiye. E-posta: yakarasahin@ku.edu.tr ORCID: 0000-0002-3611-3627

Atıf: Karasahin YA, "Zilyetliğin Havalesinde Üçüncü Kişinin Hukukî Durumu ve Kiralananın Devrinde Kiracının Hukukî Durumu ile Karşılaştrrıması" (2021) 79(3) İstanbul Hukuk Mecmuası 929. https://doi.org/10.26650/mecmua.2021.79.3.2218 
third party. However, the third party can refuse delivery to the transferee based on the same defenses that could be invoked against the transferor (Article 979/III CC). Contrary to the prevailing view in Turkish and Swiss literatures, this study argues that the above-referenced provision allows the third party to invoke defenses based on personal rights besides those based on property rights. However, this provision is only applicable to the transfer of indirect possession of chattel. In contrast to a recent opinion in Swiss literature, notice of the transfer does not cause the transferee to become a new party to the legal relationship between the original third-party bailee and transferor. Turkish and Swiss law includes only a provision about lease contracts to that effect. This provision is applicable with regard to the lease of personal and real property. However, in contracts for the lease of chattels, Article 979/III CC, as interpreted in this study, would have been sufficient to protect the lessee's interests without a disproportionate interference in the freedom of contract.

\section{Keywords}

Transfer of Indirect (Constructive) Possession, Personal Right, Lease Contract, Chattel, Defense

\section{Extended Summary}

Turkish and Swiss Civil Codes (CC) allow the transfer of indirect possession (mittelbarer Besitz) (la possession médiate) (constructive possession) by an agreement between the transferor and the transferee (Besitzanweisung) (la délegation de possession) (Art 979/I Turkish CC, Art 924/II Swiss CC). The consent of the socalled "third party," who has direct possession (unmittelbarer Besitz) (la possession immédiate) (actual possession), is not required for the transfer of indirect possession. In other words, in contrast with English law, it is not necessary that the third party in actual possession attorns to the transferee with the consent of the transferor.

Because the transferee can acquire indirect possession of and-as a result-a proprietary right on chattels (chose in possession) without the consent or knowledge of the third party, Turkish and Swiss Civil Codes contain rules for protecting the interests of the third party.

Turkish and Swiss Civil Codes stipulate that the transfer of indirect possession by an agreement between the transferor and the transferee has legal effect on the third party only after the transferor's notice to the third party (Art 979/II Turkish CC, Art 924/II Swiss CC). Prior to this notice, the acquisition of indirect possession by the transferee and its legal results, such as the acquisition of property rights in chattel, cannot be asserted against the third party. Thus, the third party is still the so-called "mediator of possession" (Besitzmittler) for the transferor and can return the property directly to the transferor. In other words, the third party would still hold the chattel as bailee of the transferor. Upon receipt of notice of the transfer, the third party becomes the "mediator of possession" for the transferee as if the third party attorned to the transferee and holds the chattel as bailee of the transferee.

Furthermore, Turkish and Swiss Civil Codes each provide that the third party can refuse delivery of the property to the transferee based on the same defenses that could have previously been invoked against the transferor (Art 979/III Turkish CC, Art 924/ III Swiss CC). The interpretation of this provision is, however, very controversial. 
In Turkish and Swiss literatures, the provision is interpreted narrowly. It is generally accepted that the third party cannot refuse delivery based on this provision if the third party has only a personal right (ius in personam) against the transferor, whereas the transferee has acquired a property right (ius in rem) through the transfer of indirect possession. This interpretation renders the provision virtually meaningless and leaves the third party with only a personal right against the transferor essentially defenseless against the transferee. If this interpretation is accepted, the transferor and the transferee can easily undermine the legal position of the third party by agreement between themselves.

This article presents a different interpretation of the mentioned provision. In the author's opinion, this provision is only applicable when the transfer of indirect possession relates to chattel. In such cases, the third party can invoke personal as well as property rights against the transferee to refuse delivery. As the personal right of the third party would be based on contract rights against the transferor, this interpretation results in a statutory exception to privity of contract. Such an exception is clearly necessary to establish equity between the interests of the parties.

Indeed, if the Turkish and Swiss Civil Codes did not allow the transfer of indirect possession without the consent of the third party, the transferor and transferee would have to wait until the third party returned the chattel so that the transferor could deliver it to the transferee. In this scenario, the third party could invoke the personal right against the transferor to refuse delivery and thereby postpone the acquisition of possession of and a proprietary right in the chattel by the transferee. As the Codes allow the transfer of indirect possession by agreement between transferor and transferee, they prevent such a postponement, thereby improving the legal position of the transferor and the transferee. However, this improvement should not be at the expense of the third party. The legal position of the third party can only be protected if the third party can invoke the personal right to refuse delivery against the transferee in addition to the transferor.

In Swiss literature, some authors argue that the notice of transfer to the third party has the effect that the transferee becomes, by operation of law, a new party to the contract between the transferor and third party, replacing the transferor. Based on this operation, the third party should be able to invoke personal contract rights against the transferee because the transferee has become a party to this contract. In this article, this interpretation is rejected because it forces the third party into a contractual relationship with the transferee and relieves the transferor from the transferor's contractual obligations without the consent of the third party.

In Turkish and Swiss law, the Code of Obligations (CO) sets out a special provision regarding the transfer of leased property. Pursuant to this provision, if the ownership 
of leased property is transferred by the lessor after the conclusion of the lease contract, the transferee replaces the transferor as the lessor (Art 310 Turkish CO, Art 261 Swiss $\mathrm{CO}$ ). In other words, the lease contract continues to exist between the lessee and the transferee. Therefore, the lessee can invoke the personal contract rights arising out of the lease contract against the transferee. This provision constitutes a disproportionate interference in the freedom of contract of the lessee when the leased property is a chattel. This disproportion is the result of the lessee being obligated to continue the contractual relationship with the transferee, even though this continuation is not necessary to protect the lessee. Once the leased chattel is delivered to the lessee, its ownership can only be assigned by the transfer of indirect possession by an agreement between transferor and transferee. As explained above, the better interpretation of the relevant provision of the Turkish and Swiss Civil Codes provides for sufficient protection of the third party (i.e., the lessee) in such cases.

\section{Zilyetliğin Havalesinde Üçüncü Kişinin Hukukî Durumu ve Kiralananın Devrinde Kiracının Hukukî Durumu ile Karşılaştırılması}

\section{Giriş}

Eşyanın dolaylı zilyedi olan kişinin (devredenin) başka bir kişiye (devralana) dolaylı zilyetlik kazandırması, Türk ve İsviçre hukuklarında zilyetliğin havalesi sözleşmesi ile olmaktadır. Devreden ve devralan arasındaki bu sözleşmenin kurulması için taşınırın dolaysız zilyedi olan kişinin (üçüncü kişinin) rızası gerekli değildir. Bu nedenle, kanun koyucu üçüncü kişinin hukukî durumunu korumak için çeşitli düzenlemeler öngörmüştür. Bu makalenin konusunu söz konusu düzenlemeler oluşturmaktadır.

Makalede ilk olarak Türk ve İsviçre hukuklarında zilyetliğin havalesi hakkında genel bilgiler verilecektir (I.). Bu genel bilgilerden sonra, zilyetliğin havalesinin üçüncü kişiye bildirilmesinin hukukî sonucu ve bu bildirimden önce üçüncü kişinin hukukî durumu açıklanacaktır (II.). Bu açıklamaları müteakip, üçüncü kişinin devredene karşı olan savunmalarını devralana karşı ileri sürebilmesine dair kanun hükmü ele alınacaktır (III.). Bu hükmün yorumlanması doktrinde ciddî tartışma konusu olmuştur ve eşya hukuku ile borçlar hukukunun temel bazı meselelerinin ele alınmasını gerektirmektedir. ${ }^{1}$ Söz konusu hükmün yorumlanması, kiralananın devrine dair kanun hükümlerinin yorumu ile karşılıklı etkileşim içindedir. $\mathrm{Bu}$ nedenle, zilyetliğin havalesinde üçüncü kişinin hukukî durumu ele alınırken, kiralananın devrinde kiracının hukukî durumu ile birlikte inceleme yapılması yararlı

\footnotetext{
Alman hukukunda aynı işlevi yerine getiren kanun hükmü (AlmMK § 986/II) açısından bu yönde Raimund Waltermann, ‘§ 986 Abs. 2 BGB als Ausdruck einer Verdinglichung schuldrechtlicher Rechtspositionen durch das Gesetz? - Zur Rechtsstellung des schuldrechtlich berechtigten Besitzers' [1993] JURA 521, 522.
} 
(hatta zorunlu) olmaktadır. Son olarak, bu makalede Türk ve İsviçre hukukları açısından savunulan görüşün Alman hukukundaki düzenlemeler ile benzerlikleri ortaya konacaktır (IV.).

\section{Türk ve İsviçre Hukukunda Zilyetliğin Havalesi Hakkında Genel Bilgiler}

Türk Medenî Kanunu’nun “[t]eslimsiz devir” kenar başlıklı 979. maddesinin ilk fikrasına göre, "[b]ir üçüncü kişi [...] özel bir hukukî ilişkiye dayanarak zilyet olmakta devam ederse zilyetlik, teslim gerçekleşmeksizin kazanılmış olur". Zilyetliğin bu şekilde teslimsiz devri, Türk ve İsviçre doktrinlerinde zilyetliğin havalesi (Besitzanweisung, délégation de possession) olarak adlandırılmaktadır. ${ }^{2} \mathrm{Bu}$ durumda, eşyanın dolaylı zilyedi olan kişi (devreden) başka bir kişi (devralan) ile sözleşme ${ }^{3}$ yaparak ona dolaylı zilyetlik kazandırmaktadır. ${ }^{4}$ Zilyetliğin havalesinin gündeme gelebilmesi için, dolaysız zilyedin yanında bir veya birden çok dolaylı zilyetten oluşan basamaklı (dereceli) zilyetlik mevcut olmalıdır. ${ }^{5}$ Zilyetliğin havalesi

Alman doktrininde 'zilyetliğin havalesi' kavramı başka bir anlamda kullanılmaktadır. Bu konuda bkz aşağıda dn 122.

Zilyetliğin havalesinin sözleşme teşkil etmesi hakkında bkz Jale G Akipek ve Turgut Akıntürk, Eşya Hukuku (Beta 2009) 154-55; A Homberger, Kommentar zum Schweizerischen Gesetzbuch, Band IV: Das Sachenrecht, Dritte Abteilung: Besitz und Grundbuch (2. Bası, Schulthess 1938) Art 924 para 5; Jörg Schmid ve Bettina Hürlimann-Kaup, Sachenrecht (5. Bası, Schulthess 2017) para 169; A Lâle Sirmen, Eşya Hukuku (8. Bası, Yetkin 2020) 66; Paul-Henri Steinauer, Les droits réels, vol 1 (5. Bası, Stämpfli 2012) para 274; Mehmet Ünal ve Veysel Başpınar, Şekli Eşya Hukuku (10. Bası, Savaş 2018) 160.

4 Zilyetliğin havalesi ile devreden kendisi zilyet kalmayacak şekilde dolaylı zilyetliğini aynen devralana geçirebilir veya kendisi dolaylı zilyet kalarak devralana yeni bir dolaylı zilyetlik kazandırabilir. Doktrinde bazı yazarlar ikinci durumu zilyetliğin tesisen kazanılması olarak nitelendirmektedir. Bu konuda bkz Aydın Aybay ve Hüseyin Hatemi, Eşya Hukuku (Vedat 2009) § 6 para 2; Şeref Ertaş, Eşya Hukuku (13. Bası, Barış 2017) para 165; Hüseyin Hatemi, Eşya Hukuku (On İki Levha 2020) 21; Hüseyin Hatemi, Rona Serozan ve Abdülkadir Arpac1, Eşya Hukuku (Filiz 1991) 255; M Kemal Oğuzman, Özer Seliçi ve Saibe Oktay-Özdemir, Eşya Hukuku (22. Bası, Filiz 2020) para 336; Rona Serozan, Eşya Hukuku I (3. Bası, Filiz 2014) para 476; Ünal ve Başpınar (n 3) 144.

5 Akipek ve Akıntürk (n 3) 153; Wolfgang Ernst, 'Art. 924 ZGB', Heinrich Honsell, Nedim Peter Vogt ve Thomas Geiser (edr), Basler Kommentar - Zivilgesetzbuch II (5. Bas1, Helbing Lichtenhahn 2015) para 3; Melchior Happel, Die Besitzessurrogate im schweizerischen Sachenrecht (Helbing Lichtenhahn 2012) 49-50; Schmid ve Hürlimann-Kaup (n 3) para 166; Emil W Stark ve Barbara Lindenmann, Berner Kommentar, Kommentar zum Schweizerischen Privatrecht, Der Besitz, Art. 919-941 ZGB (4. Bas1, Stämpfli 2016) Art 924 para 6; Thomas Sutter-Somm, Schweizerisches Privatrecht, Band V/1: Eigentum/Besitz (2. Bası, Helbing Lichtenhahn 2014) para 1278; Ünal ve Başpınar (n 3) 160. 
dolaylı zilyet(ler) tarafından kullanılabilecek bir zilyetliğin devri ${ }^{6}$ yöntemidir. ${ }^{7}$ Zilyetliğin havalesi ile ilgili hükümler açısından üçüncü kişi(ler), devredene göre fer'î zilyet ${ }^{8}$ konumunda olan kişi(ler)dir. ${ }^{9}$ Dolayısıyla, üçüncü kişi 'zilyetlik aracısı' konumundadır. 'Zilyetlik aracısı' (Besitzmittler) veya 'aracı kişi' ${ }^{10}$ (Mittelsperson) tabirleri, Alman ve İsviçre doktrinlerinde, başka birinin eşyanın dolaylı zilyedi olmasına aracı (vasıta) olan kişiyi ifade etmek için kullanılmaktadır. ${ }^{11}$ Üçüncü kişinin kendisinin eşyanın dolaysız veya dolaylı zilyedi olması mümkündür. ${ }^{12}$

Zilyetliğin havalesi, üçüncü kişinin bilgisi ve rızası olmaksızın, sadece devreden ile devralan arasında yapılan bir sözleşme ile gerçekleştirilebilmektedir. ${ }^{13}$ Bu nedenle, kanunda üçüncü kişinin korunması için bazı düzenlemeler kabul edilmiştir.

\section{Zilyetliğin Havalesinin Üçüncü Kişiye Bildirilmesi ve Bildirimden Önce Üçüncü Kişi Açısından Hüküm Doğurmaması}

Türk Medenî Kanunu'nun 979. maddesinin 2. fikrasına göre, zilyetliğin havalesi yoluyla devir 'zilyet olmakta devam eden üçüncü kişiye karşı, ancak durumun

6 Burada zilyetliğin devri kavramı, zilyetliğin tesisen kazanılmasını da kapsayacak șekilde geniș anlamda kullanılmaktadır. Zilyetliğin devren kazanılmasına bu şekilde anlam verilmesi hakkında bkz Akipek ve Akıntürk (n 3) 145; Turhan Esener ve Kudret Güven, Eşya Hukuku (7. Bası, Yetkin 2017) 81; Halûk Nami Nomer ve Mehmet Serkan Ergüne, Eşya Hukuku (7. Bası, On İki Levha 2019) para 124; Sirmen (n 3) 57; Selahattin Sulhi Tekinay ve diğerleri, Tekinay Eşya Hukuku, Cilt I (5. Bası, Filiz 1989) 68 dn 1a; Peter Tuor ve diğerleri, Das Schweizerische Zivilgesetzbuch (13. Bası, Schulthess 2009) §90 para 1.

7 Bu açıklamadan da görülmektedir ki, zilyetliğin havalesi birden çok kişinin eşyanın dolaylı zilyedi olması durumunda da mümkündür. Bu durumu açıklamak için, malikin intifa hakkı kurmak üzere taşınırı intifa hakkı sahibine teslim etmesi, intifa hakkı sahibinin de kullanım ödüncü (ariyet) sözleșmesi yaparak taşınırı ödünç alana teslim etmesi örnek olarak verilebilir. Bu örnek olayda, ödünç alan dolaysız zilyettir; intifa hakkı sahibi ve malik ise dolaylı zilyettir. Bu durumda hem malik hem de intifa hakkı sahibi zilyetliğin havalesi ile başka birine zilyetlik kazandırabilir. Malik, taşınırın mülkiyetini devretmek veya taşınır üzerinde intifa hakkından sonra gelen bașka bir intifa veya rehin hakkı kurmak için bu yola başvurabilir. Devralana ilk durumda aslî zilyetlik, ikinci durumda ise fer'î zilyetlik kazandırılmaktadır. İntifa hakkı sahibi de, henüz ödünç alan eșyanın dolaysız zilyediyken, eșyayı konu alan bir kira sözleșmesi yapabilir ve kiracıya zilyetliğin havalesi yoluyla dolaylı fer'î zilyetlik kazandırabilir. Zilyetliğin havalesi ile kazandırılan dolaylı zilyetliğin aslî veya fer'î zilyetlik olabilmesi hakkında bkz Akipek ve Akıntürk (n 3) 153; Aybay ve Hatemi (n 4) § 6 para 22; Ernst (n 5) para 3; Oğuzman, Seliçi ve Oktay-Özdemir (n 4) para 375-78; Sirmen (n 3) 65; Stark ve Lindenmann (n 5) Art 924 para 7; Steinauer (n 3 ) para 272; Ünal ve Başpınar (n 3) 161.

8 Üçüncü kişinin fer'î zilyet olması hakkında bkz Fritz Ostertag, Kommentar zum Schweizerischen Zivilgesetzbuch, Band IV: Sachenrecht, III. Abteilung: Art. 919-977 (2. Bas1, Stämpfli 1917) Art 924 para 5; Sutter-Somm (n 5) para 1278.

9 Yukarıda (bkz dn 7) açıklanan örnek olayda, intifa hakkı sahibinin zilyetliğin havalesi yoluna başvurması durumunda, ödünç alan üçüncü kişi konumunda olur. Buna mukabil, malikin zilyetliğin havalesi yoluna başvurması durumunda hem intifa hakkı sahibi hem de ödünç alan zilyetliğin havalesi hükümleri açısından üçüncü kişi konumundadır.

10 Türk doktrininde bu kavramın kullanımı için bkz Hatemi, Serozan ve Arpacı (n 4) 261; Oğuzman, Seliçi ve Oktay-Özdemir (n 4) para 381 ve 383-84; Serozan (n 4) para 524.

11 Ruth Arnet ve Paul Eitel, 'Art. 920', Peter Breitschmid ve Alexandra Jungo (edr), Handkommentar zum Schweizer Privatrecht, Sachenrecht (3. Bas1, Schulthess 2016) para 2; Homberger (n 3) Art 920 para 6; Stark ve Lindenmann (n 5) Art 924.

12 Homberger (n 3) Art 924 para 3; Stark ve Lindenmann (n 5) Art 924 para 7; Steinauer (n 3) para 273; Sutter-Somm (n 5) para 1281. Yukarıda (bkz dn 7) açıklanan olayda, malikin zilyetliğin havalesi yoluna bașvurması durumunda, intifa hakkı sahibi dolaylı zilyet, ödünç alan ise dolaysız zilyettir.

13 Tekinay ve diğerleri (n 6) 78; Ostertag (n 8) Art 924 para 4; Steinauer (n 3) para 275a. Üçüncü kişi zilyetliğin havalesinin tarafı değildir. Ernst (n 5) para 7. Üçüncü kişiye bildirimin şart olmaması hakkında bkz Sutter-Somm (n 5) para 1279. 
devreden tarafindan ${ }^{14}$ kendisine bildirildiği andan başlayarak hüküm doğurur'. Zilyetliğin havalesinin üçüncü kişiye bildiriminin hukukî sonucu hakkında doktrinde iki görüş savunulmaktadır.

\section{Türk ve İsviçre Doktrinlerinde Hâkim Olan Görüş}

Türk ve İsviçre doktrinlerinde hâkim olan ve bu makalede genel olarak kabul edilen görüsse göre, zilyetliğin havalesinin üçüncü kişiye bildirilmesinden önce, üçüncü kişi hâlen devreden için zilyetlik aracısıdır, ${ }^{15}$ dolayısıyla, devreden onun açısından hâlen dolaylı zilyettir. Bu durumda devreden de devralan için zilyetlik aracısı konumundadır ve devralan onun vasıtası ile dolaylı zilyet olmaktadır. ${ }^{16}$ Üçüncü kişi, bu aşamada eşyayı devredene iade etmesi durumunda sorumlu olmayacaktır. ${ }^{17}$ $\mathrm{Bu}$ takdirde, üçüncü kişinin devralanın dolaylı zilyetliğini ihlâl etmediğinin kabulü gerekir. Buna mukabil, zilyetliğin havalesinin üçüncü kişiye bildiriminden sonra, üçüncü kişi doğrudan devralan için zilyetlik aracısı olmaktadır. ${ }^{18}$ Bu aşamadan sonra üçüncü kişinin eşyayı devredene teslim etmesi durumunda devralanın dolaylı zilyetliği ihlâl edilmiş olacaktır.

Bu makalede savunulan görüşe göre, bildirimden önce zilyetliğin havalesinin hiçbir sonucu üçüncü kişiye karşı ileri sürülememelidir. ${ }^{19}$ Devralan zilyetliğin havalesi

14 Kanun hükmüne göre üçüncü kişiye bildirimin devreden tarafından yapılması gerekmektedir. Ancak, devredenin devralana bu konuda temsil yetkisi vermesi durumunda, bildirimin devreden adına ve hesabına devralan tarafindan yapılması da mümkündür. Mehmet Serkan Ergüne, Taşııır Mülkiyeti (On İki Levha 2017) para 295; Happel (n 5) 59-60; Homberger (n 3) Art 924 para 7; Nomer ve Ergüne (n 6) para 148; Oğuzman, Seliçi ve Oktay-Özdemir (n 4) para 383; Ostertag (n 8) Art 924 para 11; Schmid ve Hürlimann-Kaup (n 3) para 173; Steinauer (n 3) para 277.

15 Schmid ve Hürlimann-Kaup (n 3) para 171.

16 Happel (n 5) 60; Homberger (n 3) Art 924 para 6.

17 Akipek ve Akıntürk (n 3) 155; Ergüne (n 14) para 296; Homberger (n 3) Art 924 para 6; Nomer ve Ergüne (n 6) para 148; Oğuzman, Seliçi ve Oktay-Özdemir (n 4) para 381; Schmid ve Hürlimann-Kaup (n 3) para 171; Serozan (n 4) para 502; Stark ve Lindenmann (n 5) Art 924 para 22; Steinauer (n 3) para 276; Sutter-Somm (n 5) para 1279; Tekinay ve diğerleri (n 6) 78; Tuor ve diğerleri (n 6) § 90 para 11; Ünal ve Başpınar (n 3) 162. Üçüncü kişinin kendisine bildirim yapılmasından önce zilyetliğin havalesinden haberdar olması durumunda eşyayı devredene iade edebilmesine sınırlama getiren çeşitli görüşler doktrinde savunulmaktadır. Bir görüşe göre, üçüncü kişi bu durumda devredene ahlâka aykırı bir fiille kasten zarar vermesi nedeniyle Türk Borçlar Kanunu'nun 49. maddesinin 2. fikrası uyarınca sorumlu olabilir. Bu yönde Nomer ve Ergüne (n 6) para 148; Oğuzman, Seliçi ve Oktay-Özdemir (n 4) para 381. Başka bir görüşe göre, bu tür bir durumda üçüncü kişinin davranışının dürüstlük kuralına aykırı olması nedeniyle, zilyetliğin havalesinin ona bildirilmemiş olması dikkate alınmaz ve zilyetliğin havalesi üçüncü kişiye bildirilmiş gibi hüküm ve sonuç doğurur. Bu yönde Akipek ve Akıntürk (n 3) 155; Ergüne (n 14) para 296; Nomer ve Ergüne (n 6) para 148; Tekinay ve diğerleri (n 6) 79. Ayrıca, yaratılmış olan görünüşten dolaylı zilyetliğin devredildiğinin açıkça anlaşılabilmesi durumunda, zilyetliğin devrinin bildirimden önce de üçüncü kişiye karşı ileri sürülebileceği belirtilmektedir. Bu yönde Esener ve Güven (n 6) 87.

18 Homberger (n 3) Art 924 para 6. Alman hukukunun benzer düzenlemesi (AlmMK § 870) açısından, dolaylı zilyetliğin zilyetlik aracısının iradesine dayanması kuralına kanun koyucu tarafından istisna getirildiği belirtilmektedir. Bu yönde Hans Wieling, 'Voraussetzungen, Übertragung und Schutz des mittelbaren Besitzes' (1984) 184 AcP 439, 457. Devredenin zilyetliğinin aynen devralana geçmesi için (mesela taşınır mülkiyetinin nakli için) zilyetliğin havalesi yapılırsa, üçüncü kişiye bildirimden sonra devreden zilyetlik zincirinden çıkmış olacaktır. Buna mukabil, devreden (mesela taşınırın maliki) kendisi de dolaylı zilyet kalacak şekilde devralana dolaylı zilyetlik kazandırmak üzere (mesela devralana intifa hakkı kazandırmak için) zilyetliğin havalesi yaparsa, devreden (malik) zilyetlik zincirinde kalacaktır; ancak üçüncü kişiye bildirimden sonra devralana (intifa hakkı sahibine) göre zincirin bir sonraki aşamasında bulunacaktır. Bu durumda, üçüncü kişi, doğrudan devralan (intifa hakkı sahibi) için zilyetlik aracısıdır ve kendisinin zilyet olmasına sebep teşkil eden ilişki sona erince eșyayı devralana (intifa hakkı sahibine) teslim etmelidir. Devralan (intifa hakkı sahibi) ise, devreden (malik) için zilyetlik aracısıdır ve kendisinin zilyet olmasına sebep teşkil eden ilişki (intifa hakkı) sona erince eşyayı devredene (malike) teslim etmelidir.

19 Aynı yönde Ergüne (n 14) para 296. 
sonucunda taşınır üzerinde mülkiyet veya intifa hakk1 ${ }^{20}$ kazandıysa, zilyetliğin havalesinin üçüncü kişiye bildiriminden önce bu hakkın ona karşı ileri sürülmesi mümkün olmamalıdır. ${ }^{21}$ Dolayısıyla, devreden ile devralan arasındaki aynî sözleşme açısından, üçüncü kişiye bildirimden önce nisbî hükümsüzlük (nisbî etkisizlik) söz konusudur. ${ }^{22}$ Bu durumda, 743 sayılı (önceki) Türk Kanunu Medenîsi’nin 690. maddesi ve İsviçre Medenî Kanunu'nun 717. maddesi uyarınca, taşınır mülkiyetinin üçüncü kişileri zarara sokmak veya taşınır rehni kurallarından kurtulmak için hükmen teslim ile devri durumunda ortaya çıkan nisbî hükümsüzlüğe benzer bir durum söz konusudur. ${ }^{23}$

Burada savunulan görüşün bir sonucu, Türk Borçlar Kanunu’nun 310. ve 311. maddelerinin uygulanması açısından ortaya çıkacaktır. Devralan zilyetliğin havalesi yoluyla kiralanan taşınır üzerinde mülkiyet veya intifa hakkı kazansa bile, bu hak zilyetliğin havalesinin bildiriminden önce üçüncü kişiye (yani kiracıya) karşı ileri sürülemediğinden kira sözleşmesinin hâlen üçüncü kişi (kiracı) ile devreden arasında olduğu kabul edilmelidir. Dolayısıyla, kira sözleşmesinden doğan hak ve yükümlülükler, üçüncü kişiye (kiracıya) bildirim anına kadar devredene ait olacaktır. Özellikle kiraya verenin yükümlülüklerinin ihlâli nedeniyle sorumluluk (mesela ayıptan doğan sorumluluk) açısından bu durum önemli olabilir.

İsviçre Borçlar Kanunu'nun kira sözleşmesi ile ilgili hükümlerinde değişiklik yapan kanunun gerekçesine ${ }^{24}$ ve İsviçre doktrininde bir yazar tarafından açıkça kabul edilen görüşe göre, ${ }^{25}$ kiralanan taşınırın mülkiyetinin zilyetliğin havalesi yoluyla devredilmesi durumunda, İsviçre Borçlar Kanunu'nun 261. maddesinin ilk fikrası (Türk Borçlar Kanunu'nun 310. maddesi) zilyetliğin havalesini içeren sözleşmenin

20 Zilyetliğin havalesi yoluyla taşınır rehni kurulması için üçüncü kişiye bildirim yapılması şarttır. Bu nedenle, üçüncü kişiye bildirim yapılmaksızın devralana zilyetliğin havalesi yoluyla kazandırılabilecek tek sınırlı aynî hak intifa hakkıdır.

21 Mülkiyet açısından açıkça bu yönde Hatemi, Serozan ve Arpacı (n 4) 260.

22 Başak Başoğlu, Mülkiyeti Saklı Tutma Anlaşması (Vedat 2019) 83; Ergüne (n 14) para 296 dn 284; Hatemi, Serozan ve Arpacı (n 4) 260; Ünal ve Başpınar (n 3) 161-62.

23 Hatemi, Serozan ve Arpacı (n 4) 260; Serozan (n 4) para 504. Ayrıca bkz Ergüne (n 14) para 283 ve para 296 dn 284. 4721 sayılı Türk Medenî Kanunu'nun 766. maddesine göre, bu hükme aykırılık hâlinde "mülkiyetin nakli sonuç doğurmaz". Hükümde kullanılan ifade nedeniyle, 743 sayılı (önceki) Türk Kanunu Medenîsi'nden ve İsviçre Medenî Kanunu'ndan farklı olarak, bu maddeye aykırılık durumunda nisbî hükümsüzlük değil, kesin hükümsüzlük yaptırımının öngörüldügünü kabul eden yazarlar bulunmaktadır. Bu yönde Oğuzman, Seliçi ve Oktay-Özdemir (n 4) para 2612; Sirmen (n 3) 540; Gülşah Vardar Hamamcıoğlu, Medenî Hukuk ta Tasarruf Işslemi Kavramı (On İki Levha 2014) 253-54. Ayrıca bkz Necip Kocayusufpaşaoğlu, Borçlar Hukukuna Giriş - Hukukî İşlem - Sözleşme (4. Bası, Filiz 2008) § 43 para 37. Ancak, 4721 sayılı Türk Medenî Kanunu'nun 766. maddesinin hâlen nisbî hükümsüzlük yaptırımını öngördüğünü kabul eden yazarlar da bulunmaktadır. Bu yönde Akipek ve Akıntürk (n 3) 585; Aybay ve Hatemi (n 4) § 17 para 58; Ergüne (n 14) para 282; Ertaş (n 4) para 2235; Nomer ve Ergüne (n 6) para 856; Serozan (n 4) para 199 ve 1224.

24 Botschaft zur Volksinitiative 'für Mieterschutz', zur Revision des Miet- und Pachtrechts im Obligationenrecht und zum Bundesgesetz über Massnahmen gegen Missbräuche im Mietwesen (Botschaft zur Revision des Miet- und Pachtrechts) vom 27. März 1985, [1985] I BB1 1389, 1440: ‘ ...bei der Veräusserung beweglicher Sachen geht es mit dem Abschluss des Veräusserungsvertrages über, wenn sich die Sache im Besitz eines Dritten, zum Beispiel des Mieters, befindet (vgl. Art. 924 Abs. 1 ZGB).'

25 Bettina Hürlimann-Kaup, Grundfragen des Zusammenwirkens von Miete und Sachenrecht (Schulthess 2008) para 537 ve 586. 
(taşınır mülkiyetinin devrine yönelik aynî sözleşmenin) ${ }^{26}$ yapılması anında devreye girecektir. Dolayısıyla, devreden ile devralan arasındaki sözleşmenin yapılması (daha doğrusu: hüküm ve sonuç doğurması) anında, devralan kira sözleşmesinin tarafi ve kira bedelinin alacaklısı olacaktır. Bu görüş kabul edilirse, üçüncü kişinin (kiracının) kendisine bildirim yapılmasından önce kira bedelini iyiniyetle devredene ödemesi durumunda, İsviçre Borçlar Kanunu'nun 167. maddesinin (Türk Borçlar Kanunu'nun 186. maddesinin) kıyasen uygulanması sonucunda borcundan kurtulduğunun kabulü gerekir. $^{27}$

Kira bedeli ödeme borcundan kurtulma açısından, burada savunulan görüş ile aktarılan karşı görüş arasında esaslı bir fark doğmamaktadır. ${ }^{28}$ Ancak, zilyetliğin havalesi ile üçüncü kişiye bildirim arasındaki dönemde kiralananın ayıplı hâle gelmesi durumunda kiracıya karşı sorumlunun belirlenmesi açısından önemli bir fark ortaya çıkabilir.

\section{2. İsviçre Doktrininde Savunulan Yeni Görüş}

İsviçre doktrininde savunulan yeni görüşe göre, zilyetliğin havalesinin üçüncü kişiye bildirilmesi üzerine, üçüncü kişi ile devreden arasındaki hukukî ilişkide devredenin yerini devralan alır. Bu görüş, Türk Medenî Kanunu’nun 979. maddesinin 3. fikrası (İsviçre Medenî Kanunu’nun 924. maddesinin 3. fikrası) hakkında açıklama yapılırken ileride ele alınacaktır.

\section{III. Üçüncü Kişinin Devredene Yönelik Savunmalarını Devralana İleri Sürebilmesi}

Türk Medenî Kanunu'nun 979. maddesinin 3. fikrasına göre, '[ü]]çüncü kişi, zilyetliği devredene karşı ileri sürebileceği sebeplerle şeyi edinene vermekten kaçınabilir'. Birden çok dolaylı zilyetten oluşan, çok basamaklı zilyetlik söz konusu ise hem dolaysız zilyedin hem de dolaylı zilyet olan üçüncü kişinin (devreden için

26 Doktrinde savunulan ilk görüşe göre, mülkiyetin devri konusunda anlaşma ve zilyetliğin devri, aynî sözleşmenin iki kurucu unsurudur. Bu yönde Sirmen (n 3) 535. Doktrinde savunulan diğer görüşe göre ise, aynî sözleşmenin tek kurucu unsuru, mülkiyetin devri konusunda anlaşmadır. Zilyetliğin devri ise, aynî sözleşmenin hüküm doğurması için aranan tamamlayıcı bir unsurdur. Bu yönde Ergüne (n 14) para 227; Kocayusufpaşaoğlu (n 23) § 11 para 6.

27 Türk doktrininde bu yönde Murat İnceoğlu, Kira Hukuku (On İki Levha 2014) Cilt I, 595; Seda Öktem Çevik, Kira Sözleșmesine Etkisi Bakımından Kiralananın Devri ve Sinırlı Ayni Hakka Konu Olması (On İki Levha 2016) 203-05. 6570 sayılı (mülga) Gayrimenkul Kiraları Hakkında Kanun açısından bu yönde Burak Özen, 'Kira Konusunun Devri' (2010) 16/1-2 MÜHF - HAD 137, 175-76.

28 İki görüş arasındaki fark, devredene kira bedelini ödeyen kiracının (zilyetliğin havalesi açısından üçüncü kişinin) borcundan kurtulması için iyiniyetinin şart olup olmaması açısından ortaya çıkmaktadır. Burada savunulan görüşe göre, zilyetliğin havalesinin bildiriminden önce devredene kira bedelini ödeyen kiracının (zilyetliğin havalesi açısından üçüncü kişinin) borcundan kurtulması için iyiniyetli olması șart değildir. Ancak, üçüncü kișinin (kiracının) bildirimden önce zilyetliğin havalesinden haberdar olması durumunda, zilyetliğin havalesinin ona karşı ileri sürülememesi kuralına sınırlamalar getiren görüşler bulunmaktadır. Bu konuda bkz yukarıda dn 17. Bu görüşlerin üçüncü kişinin (kiracının) kira bedelini devredene ödemesi açısından da savunulması mümkündür. Bu durumda, yukarıda açıklanan iki görüş arasındaki fark iyice azalmaktadır. 
zilyetlik aracısı olan kişinin) $)^{29}$ bu hükümde düzenlenen imkândan yararlanabilmesi mümkündür. ${ }^{30} \mathrm{Bu}$ durumda, dolaysız zilyet, dolaylı zilyet olan üçüncü kişinin devredene karşı sahip olduğu savunmaları devralana karşı ileri sürerek eşyayı devralana vermekten kaçınabilir. ${ }^{31}$

Söz konusu hüküm hakkında doktrinde üç görüş savunulmaktadır. Aşağıda, ilk olarak, makalede savunulan görüş açıklanacaktır (1.). İkinci olarak, Türk ve İsviçre doktrinlerinde hâkim olan görüş ele alınacaktır (2.). Son olarak da, İsviçre doktrininde son dönemlerde savunulmaya başlanan yeni görüş açıklanacak ve değerlendirilecektir (3.).

\section{Makalede Kabul Edilen Görüşs}

\section{A. Genel Olarak}

İsviçre doktrininde bazı yazarlar tarafından savunulan ve bu makalede de kabul edilen görüşe göre, Türk Medenî Kanunu'nun 979. maddesinin 3. fikrası (İsviçre Medenî Kanunu'nun 924. maddesinin 3. fıkrası) uyarınca, taşınırların zilyetliğinin havalesi durumunda, üçüncü kişi tarafından devredene karşı ileri sürülebilen bütün aynî veya şahsî (nisbî) haklar devralana karşı da ileri sürülerek taşınırın iadesinden kaçınılabilir. ${ }^{32}$ Üçüncü kişinin aynî hakkını devralana karşı ileri sürebilmesi bu hakkın mutlak hak olmasından kaynaklanmaktadır. Bu açıdan bir özellik söz konusu değildir. Dolayısıyla, özel olarak üzerinde durulması gereken husus, üçüncü kişinin devreden ile ilişkisinden doğan şahsî (nisbî) hakkının devralana karşı da ileri sürülebilmesidir.

Burada savunulan görüşe göre, ilk olarak, taşınırlar ve taşınmazlar arasında bir ayrım yapılmalıdır. Taşınır mülkiyetinin devri ve taşınır üzerinde intifa veya rehin hakkı kurulması için kural olarak taşınırın zilyetliğinin devri şarttır (TMK 763/I, 795/I ve 939/I, İsvMK 714/I, 745/I ve 884/I). Eğer kanunda zilyetliğin havalesi öngörülmemiş olsaydı, üçüncü kişinin taşınırın dolaysız zilyedi olması nedeniyle devredenin (sadece) dolaylı zilyet olması durumunda, devreden tarafindan devralana aynî hak kazandırılabilmesi için taşınırın üçüncü kişi tarafından devredene iadesinin ve devreden tarafindan devralana tesliminin beklenmesi gerekecekti. Bu durumda, üçüncü kişi devredene karşı şahsî (nisbî) hakkını ileri sürerek taşınırın iadesinden

29 Bu açıklamaya örnek olarak, taşınırın malik tarafından intifa hakkı sahibine teslimi, intifa hakkı sahibi tarafından da ödünç alana teslim edilmesi gösterilebilir. Malikin zilyetliğin havalesi yoluyla dolaylı zilyetliğini devretmesi durumunda, hem dolaysız zilyet olan ödünç alan hem de dolaylı zilyet olan intifa hakkı sahibi burada incelenen hüküm açısından üçüncü kişidir.

30 Stark ve Lindenmann (n 5) Art 924 para 40.

31 Ostertag (n 8) Art 924 para 12.

32 Eugen Bucher, Obligationenrecht Besonderer Teil (3. Bas1, Schulthess 1988) 173; Paul Eitel, 'Bricht Kauf Miete und Leihe bei Fahrnis?', Wolfgang Wiegand, Thomas Koller ve Hans Peter Walter (edr), Tradition mit Weitsicht - Festschrift für Eugen Bucher zum 80. Geburtstag (Stämpfli 2009) 69, 73 vd; Martin P Hedinger, System des Besitzesrechts (Stämpfli 1985) 86-87; Felix Schöbi, Der Besitzesschutz (Stämpfli 1987) 63. Hem taşınırlar hem de taşınmazlar açısından bu yönde Adolf Zycha, 'Eigentumsverfolgung und Verkehrsschutz bei Fahrnis nach dem Schweizerischen Civil-gesetzentwurfe' (1903) 22 ZSR 74, 135 özellikle dn 126. 
kaçınabilir ve devralanın aynî hak kazanmasını geciktirebilirdi. Zilyetliğin havalesi yoluyla üçüncü kişinin rızası ve bilgisi olmaksızın dolaylı zilyetliğin devredilebilmesi, taşınırın devredene iadesinin beklenmesi zorunlu olmaksızın, devreden tarafından devralana (dolaylı zilyetlik ve) aynî hak kazandırılması imkânını yaratmaktadır. ${ }^{33}$ Burada kabul edilen görüşe göre, üçüncü kişinin rızası (hatta bilgisi) olmaksızın yapılabilen bu devir, onun menfaatlerinin zedelenmesine hiçbir şekilde yol açmamalıdır. ${ }^{34} \mathrm{Bu}$ nedenle, üçüncü kişi tarafindan devredene ileri sürülebilen bütün savunmalar - şahsî (nisbî) hakka dayansalar bile - devralana karşı da ileri sürülebilmelidir. Bu görüş, devralanın menfaatleri açısından da sakıncalı değildir. Nitekim, zilyetliğin havalesi yolu kabul edilmemiş olsaydı, devralan aynî hak kazanabilmek için zaten üçüncü kişinin aynî hakkının veya devredene karşı ileri sürülebilen şahsî (nisbî) hakkının sona ermesini ve taşınırın devredene iadesini beklemek zorunda olacaktı. Devralanın üçüncü kişinin şahsî (nisbî) hakkı sona ermeden taşınır üzerinde aynî hak kazanabilmesi, taşınırın kendisine teslimi için üçüncü kişinin aynî veya şahsî (nisbî) hakkının sona ermesini beklemesi gerekse bile, neticede onun menfaatinedir.

Türk Medenî Kanunu'nun 979. maddesinin 3. fikrasının (İsviçre Medenî Kanunu'nun 924. maddesinin 3. fikrasının) yorumunda taşınır üzerinde aynî hak kazanılmasının yolu açısından da bir ayrım yapılmalıdır. Yukarıda yer alan açıklamalar, taşınır mülkiyetinin devri veya taşınır üzerinde sınırlı aynî hak kurulması için zilyetliğin devrinin şart olduğu hâller dikkate alınarak yapılmıştır. Zilyetliğin devri şart olmaksızın devralana taşınır üzerinde aynî hak kazandırılan hâllerde hukukî durum değişmektedir. Bu durumda, zilyetliğin havalesi kanunda kabul edilmemiş olsaydı bile, üçüncü kişinin taşınırın dolaysız zilyedi olması devralanın aynî hak kazanmasına engel olmazdı. Bu nedenle, zilyetliğin havalesi durumunda üçüncü kişiye sağlanan koruma devreye girmemelidir.

Taşınmazlar ile ilgili hukukî durum da taşınırlar ile ilgili genel hukukî durumdan farklıdır. Nitekim taşınmaz mülkiyetinin devri ve taşınmaz üzerinde sınırlı aynî hak kurulması ya da devri için zilyetliğin devredilmesi şart değildir. Bu nedenle, üçüncü kişi taşınmazın dolaysız zilyedi olsa bile, devredenin dolaysız zilyet olmayı beklemesi gerekmeksizin devralana taşınmaz üzerinde aynî hak kazandırması mümkündür. Zilyetliğin havalesi bu açıdan bir fark yaratmamaktadır. Üçüncü kişi devredene karş1 şahsî (nisbî) hak ileri sürerek taşınmazın iadesinden kaçınabilse de, devredenin devralana aynî hak kazandırmasına engel olamayacaktır. Bu nedenle, devreden zilyetliğin havalesi ile devralana taşınmazın dolaylı zilyetliğini kazandırınca, üçüncü

33 Eitel (n 32) 73; Ünal ve Başpınar (n 3) 160. Ayrıca bkz Happel (n 5) 49; Stark ve Lindenmann (n 5) Art 924 para 6. Alman hukukunda 'iade talebinin devri' (Abtretung des Herausgabeanspruchs) yoluyla taşınır mülkiyetinin devredilebilmesinin benzer bir işleve sahip olması hakkında bkz Jürgen F Baur ve Rolf Stürner, Sachenrecht (18. Bası, CH Beck 2009) §51 para 35.

34 Karş Happel (n 5) 67-68. 
kişi tarafından devredene karş1 ileri sürülebilen şahsî (nisbî) hakların devralana karşı ileri sürülerek taşınmazın dolaysız zilyetliğinin iadesinden kaçınılamaması menfaatler dengesine uygundur.

Buraya kadar yapılan açıklamalar, Türk Medenî Kanunu'nun 979. maddesinin 3. fikrası (İsviçre Medenî Kanunu'nun 924. maddesinin 3. fikrası) açısından taşınırlar ve taşınmazlar arasında ayrım yapılması lüzumunu göstermekte ve söz konusu hükmün sadece taşınırlar açısından uygulanması görüşünün gerekçesini ortaya koymaktadır. İsviçre doktrininin aksine, ${ }^{35}$ Türk doktrininde zilyetliğin havalesi hâlinde üçüncü kişinin şahsî (nisbî) hakkını devralana karşı ileri sürerek iadeden kaçınabilmesini kabul eden yazarlar, taşınırlar ve taşınmazlar arasında bir ayrım yapmamaktadır. ${ }^{36}$ Bu durum, 4721 sayılı Türk Medenî Kanunu'nun 979. maddesinin 3. fikrasının (743 sayıl1 [önceki] Türk Kanunu Medenîsi’nin 892. maddesinin 3. fikrasının ve İsviçre Medenî Kanunu'nun 924. maddesinin 3. fikrasının) sözünde taşınırlar ve taşınmazlar arasında ayrım yapılmamasından kaynaklanıyor olabilir. Ancak menfaat durumları arasındaki fark, hükmün sözünde yer almasa da, taşınırlar ile taşınmazlar arasında bir ayrım yapılması gerektiğini göstermektedir.

$\mathrm{Bu}$ makalede savunulan görüş uyarınca, İsviçre doktrininde savunulan yeni görüşün aksine, Türk Medenî Kanunu'nun 979. maddesinin 3. fikrası (İsviçre Medenî Kanunu'nun 924. maddesinin 3. fikrası) üçüncü kişi ile devreden arasındaki hukukî ilişkide taraf değişmesine ve devredenin yerini devralanın almasına yol açmamaktadır. Borç ilişkisi üçüncü kişi ile devreden arasında kalmaya devam etmektedir. Bu nedenle, borç ilişkisinden doğan bir hakkı üçüncü kişiye karşı ileri sürebilen ve üçüncü kişiye borçlu olan tek kişi devredendir. Borca aykırılık hâlinde üçüncü kişiye karşı sorumlu olacak kişi de devredendir. Bu yönde bir düzenleme, irade serbestîsine en uygun çözüm niteliğindedir. Nitekim, Türk Borçlar Kanunu'nun 310. maddesindeki veya İsviçre Borçlar Kanunu'nun 261. maddesindeki gibi borç ilişkisinde devredenin yerini devralanın almasına dair bir düzenleme yapılması durumunda, üçüncü kişiye karşı alacaklı ve borçlu olan kişinin üçüncü kişinin rızası olmaksızın değişmesi söz konusu olacaktır. Üçüncü kişinin borç ilişkisinden doğan bütün haklarının ve borçlarının aynı kalması hâlinde bile, onun iradesi hilafına devralan ile borç ilişkisi içine sokulması menfaatlerine aykırı olabilir ve her halükârda irade serbestîsine getirilen bir sınırlama niteliğindedir. Bu tür bir sınırlamanın ölçülü olup olmadığı, aşağıda kira sözleşmesi açısından özel olarak ele alınacaktır.

\footnotetext{
Bucher (n 32) 173. Ayrıca bkz Eitel (n 32) 71 dn 10. Yazar İsviçre Medenî Kanunu’nun 924. maddesinin 3. fikrasını (Türk Medenî Kanunu'nun 979. maddesinin 3. fikrasını) sadece taşınırlar açısından ele almaktadır. Bu hükmün taşınmazlara uygulanması meselesine girmediğini belirtmektedir.

36 Ertaş (n 4) para 192; Tekinay ve diğerleri (n 6) 80-81.
} 


\section{B. Kira Sözleşmesine Dair Özel Hükümler ile Karşılaştırma}

Türk Medenî Kanunu'nun 979. maddesinin 3. fikrası (İsviçre Medenî Kanunu'nun 924. maddesinin 3. fikrası) ile ilgili bütün görüşler, bu hükmün kiralananın devri hakkındaki hükümlerle ilişkisini ele almaktadır. Bu makalede de aynı yol izlenecektir.

\section{a. 818 Sayılı Borçlar Kanunu'nun ve İsviçre Borçlar Kanunu'nun Önceki Hükümleri ile Karşılaştırma}

Bu kapsamda, ilk olarak, 818 say1lı (önceki) Borçlar Kanunu'nun 254. maddesi ve İsviçre Borçlar Kanunu'nun 01.07.1990 tarihinden önceki (ilk) hâli ile 259. maddesi ele alınmalıdır. Bu maddelerin ilk fikrasına göre, kira sözleşmesinin kurulmasından sonra kiralananın mülkiyetinin devredilmesi durumunda, devralan bu yönde irade beyanında bulunmadıkça, kiracı kira sözleşmesinin devamını ondan talep edemez. ${ }^{37}$ Maddenin ikinci fikrasına göre, kiralanan taşınmaz ise, devralan kira sözleşmesinin feshedilmesi mümkün olan ilk ana kadar kiralananın kiracı tarafından kullanılmasına katlanmakla yükümlüdür. ${ }^{38}$

Söz konusu hükümde geçen 'kiranın devamı' ifadesi, ${ }^{39}$ devralanın kira sözleşmesinden doğan borca katılmasi ${ }^{40}$ veya devralana kira sözleşmesinin devri olarak anlaşılmaktayd ${ }^{41}{ }^{41} \mathrm{Bu}$ konuda kabul edilen görüş ne olursa olsun, devralan sadece 'kiranın devamını' kabul etmesi durumunda kiracıya karşı borç altına girer ve borca aykırılık hâlinde sorumlu olurdu. Mesela kiralananın ayıplı hâle gelmesi nedeniyle devralanın kiracıya karşı sorumlu olması, sadece 'kiranın devamını' kabul etmesi hâlinde söz konusu olurdu. 818 sayılı (önceki) Borçlar Kanunu'nun 254. maddesi ve İsviçre Borçlar Kanunu'nun 01.07.1990 tarihinden önceki (ilk) hâli ile 259. maddesi, devralan açısından bu hukukî sonucun doğmasını (yani devralanın borç altına girmesini) onun iradesine bağlamıştı.

\footnotetext{
818 sayılı (mülga) Borçlar Kanunu'nun 254. maddesinin uygulama alanında olan (6570 sayılı [mülga] Gayrimenkul Kiraları Hakkında Kanun'un uygulama alanı dışında kalan) hâllerde, devralanın kiralananı kullandırma borcuna katılması veya kira sözleşmesini devralması kendi iradesine dayanıyordu. Ancak, doktrinde savunulan bir görüşe göre, devralanın iradesi bu sonuçları doğurmak için yeterli değildi. Her halükârda kiracının da irade beyanı aranmalıydı. Ayrıca, sözleşmenin devri durumunda, devredenin de katılması ile üç taraflı bir sözleşme yapılması gerekiyordu. Bu yönde Öktem Çevik (n 27) 11-12; Özen, 'Kira Konusunun Devri' (n 27) 166-67. Doktrinde savunulan diğer görüşe göre, kiralananın devri sonrasında devralanın borca katılma yönünde irade beyanında bulunması, onun kiralananı kullandırma borcuna katılması için kanunen yeterliydi. Dolayısıyla, bu görüşe göre, devralanın borca katılması için kiracının rızası aranmıyordu. Bu yönde Mustafa Alper Gümüş, Yeni 6098 Sayılı Türk Borçlar Kanunu'na Göre Kira Sözleşmesi (Vedat 2011) 138. Her halükârda, devralanın irade beyanı olmadan kendisinin kira sözleşmesine dayalı bir borcun yükümlüsü olması söz konusu değildi.

38 Bu durumda kanundan doğan bir borç olduğu kabul edilmeliydi. Bu yönde Özen, 'Kira Konusunun Devri' (n 27) 168; Öktem Çevik (n 27) 12. Başka bir görüş için bkz Gümüş (n 37) 139-40.

39818 sayılı (önceki) BK 254/I: “... kiracı, kiralananın ahiren maliki olan üçüncü şahıstan ancak kabulü şartı ile kiranın devamını [...] isteyebilir.” İsvBK 259/I (ilk hâli), Fransızca metin: “...le preneur n'a pas le droit d'imposer au tiers acquéreur la continuation du bail, à moins que ce dernier ne s'y soit obligé...” Almanca metin: “...so kann der Mieter die Fortsetzung des Mietvertrages von dem Dritten nur fordern, wenn dieser sie übernommen hat..." (Vurgular ilave edilmiştir.)

40 Bu yönde Bucher (n 32) 172.

41 Bu konudaki görüşlerin açıklanması için bkz Öktem Çevik (n 27) 10-12.
} 
Söz konusu hüküm, burada savunulan görüşe göre, devralanın kiracıya karş1 borç altına girmesi söz konusu olmaksızın, kiracının devredene karşı olan alacak hakkını devralana ileri sürerek kiralananı teslimden kaçınabilmesini engelleyecek şekilde anlaşılmamalıyd $1 .{ }^{42}$ Başka bir ifadeyle, söz konusu hüküm, Türk Medenî Kanunu'nun 979. maddesinin 3. fikrasının (743 sayılı Türk Kanunu Medenîsi'nin 892. maddesinin 3. fikrasının ve İsviçre Medenî Kanunu'nun 924. maddesinin 3. fikrasının) kira sözleşmesinde uygulanmasına engel değildi. ${ }^{43}$ Kiracının zilyetliğinde olan taşınırın mülkiyetinin zilyetliğin havalesi yoluyla devri durumunda, kiracı devreden ile olan kira sözleşmesinden doğan alacak hakkına dayanarak taşınıı iadeden kaçınabilirdi; ${ }^{44}$ ancak borca aykırılık durumunda devralanı sorumlu tutamazdı. Kiracıya karşı sorumlu olan sadece devredendi. ${ }^{45}$

Açılanan görüş kabul edilseydi, Türk Medenî Kanunu'nun 979. maddesinin 3. fikrası (743 sayılı Türk Kanunu Medenîsi'nin 892. maddesinin 3. fikrası ve İsviçre Medenî Kanunu'nun 924. maddesinin 3. fikrası) ile 818 sayılı (önceki) Borçlar Kanunu'nun 254. maddesi (İsviçre Borçlar Kanunu'nun 01.07.1990 tarihinden önceki hâli ile 259. maddesi) arasında bir çelişki meydana gelmemekteydi. ${ }^{46}$ Kira sözleşmesine dair hüküm, kiralananın devri hâlinde devralanın kira sözleşmesi uyarınca borçlu olmasını onun iradesine bağlıyordu. Zilyetliğin havalesine dair hüküm ise, zaten üçüncü kişi (kiracı) ile devralan arasında borç ilişkisi olmaması hâlini düzenliyor ve üçüncü kişinin şahsî hakkını (kira sözleşmesinden doğan alacak hakkını) ileri sürerek kiralanan taşınırı devralana iadeden kaçınabilmesini sağlıyordu. ${ }^{47}$ Ancak, Türk ve İsviçre doktrinlerinde bu görüş hâkim olmamıştır.

\section{b. 6098 Sayılı Türk Borçlar Kanunu'nun ve İsviçre Borçlar Kanunu’nun Yeni Hükümleri ile Karşılaştırma}

Türk Borçlar Kanunu'nun 310. ve 311. maddelerine (İsviçre Borçlar Kanunu'nun 261. ve 261a maddelerine) göre, kiralanan üzerinde mülkiyet hakkına veya üst

\footnotetext{
22 Rudolf Beetschen, Der Grundsatz 'Kauf bricht Miete'im schweizerischen Recht (Effingerhof 1925) 57

Aksi yönde Tekinay ve diğerleri (n 6) 81.

44 Beetschen (n 42) 58.

45 Karş Beetschen (n 42) 59.

46 Aksi yönde Homberger (n 3) Art 924 para 10; Ostertag (n 8) Art 924 para 12.

47 Bütün paragraf için bkz Beetschen (n 42) 57.
} 
hakkına ${ }^{48}$ sahip olan ${ }^{49}$ kiraya veren (devreden), kira sözleşmesinin kurulmasından ve kiralananın kiracıya tesliminden sonra, ${ }^{50}$ mülkiyet hakkını veya üst hakkını başka bir kişiye devreder veya kiracının hakkı ile çatışacak şekilde başka bir kişi lehine sınırlı aynî hak kurarsa ${ }^{51}$ (mesela intifa hakk1, oturma [sükna] hakk1 veya üst hakk1 kurarsa $^{52}$ ya da üst hakkı sahibi olan kiraya veren kiralananın kullanımını etkileyecek başka bir üst hakkı kurarsa), ${ }^{53}$ kira sözleşmesinde kiraya verenin yerini kanunen devralan alır. ${ }^{54}$ Kira sözleşmesinin tarafı hâline gelen devralan, kira sözleşmesini kanunda sayılan hâllerde sona erdirebilir (TBK 351 ve İsvBK 261/II). Dolayısıla, devreden tarafindan sona erdirilemeyen bir kira sözleşmesinin (bu sözleşmeden doğan hak tapu siciline şerh edilmediyse) devralan tarafindan belli şartlar altında daha erken sona erdirilebilmesi imkânı vardır. İsviçre hukukunda, bu ihtimal gerçekleşirse, kiracının kira sözleşmesinin erken sona erdirilmesi nedeniyle doğan zararından devreden sorumlu tutulmuştur (İsvBK 261/III). ${ }^{55}$ Türk hukukunda bu

48 Kiraya verenin üst hakkı sahibi olabilmesi ve üst hakkının devri durumunda kiralananın $\overline{\text { devrine dair hükümlerin }}$ uygulanabilmesi yönünde Hürlimann-Kaup (n 25) para 548; Öktem Çevik (n 27) 102. 818 sayılı (mülga) Borçlar Kanunu'nun 254. maddesi ve 6570 sayılı (mülga) Gayrimenkul Kiraları Hakkında Kanun açısından aynı yönde Özen, 'Kira Konusunun Devri' (n 27) 155-56. Ayrıca bkz İnceoğlu (n 27) 578; Öktem Çevik (n 27) 150-51.

49 Türk Borçlar Kanunu'nun 310. maddesinin (İsviçre Borçlar Kanunu'nun 261. maddesinin) uygulanabilmesi için, kural olarak, kiraya verenin malik olması aranmaktadır. Bu yönde Faruk Acar, Kira Hukuku Şerhi (3. Bası, Beta 2016) TBK m 310 para 35; Gümüş (n 37) 144; Hürlimann-Kaup (n 25) para 523 ve 527; İnceoğlu (n 27) 582; Öktem Çevik (n 27) 89. 818 sayı1ı (mülga) Borçlar Kanunu'nun 254. maddesi ve 6570 sayılı (mülga) Gayrimenkul Kiraları Hakkında Kanun açısından aynı yönde Özen, 'Kira Konusunun Devri' (n 27) 150-51. Ancak, kiraya veren lehine tapu sicilinde yolsuz tescil varsa ve Türk Medenî Kanunu'nun 1023. maddesi (İsviçre Medenî Kanunu'nun 973. maddesi) uyarınca devralan iyiniyetle mülkiyet hakkını kazanırsa, Türk Borçlar Kanunu’nun 310. maddesinin (İsviçre Borçlar Kanunu'nun 261. maddesinin) uygulanması savunulmaktadır. Bu görüşü kabul edenlere göre, kiraya verenin taşınırın emin sıfatıyla zilyedi olması ve Türk Medenî Kanunu'nun 988. maddesi (İsviçre Medenî Kanunu’nun 933. maddesi) uyarınca üçüncü kişinin mülkiyeti kazanması hâlinde de aynı sonuç doğar. Bu yönde Acar (n 49) TBK m 310 para 35; Hürlimann-Kaup (n 25) para 525; İnceoğlu (n 27) 579; Öktem Çevik (n 27) 137-38. 818 sayılı (mülga) Borçlar Kanunu'nun 254. maddesi ve 6570 say1lı (mülga) Gayrimenkul Kiraları Hakkında Kanun açısından aynı yönde Özen, ‘Kira Konusunun Devri’ (n 27) 151.

50 Türk Borçlar Kanunu'nun 310. ve İsviçre Borçlar Kanunu’nun 261. maddesinde kiralananın kiracıya teslim edilmesi şartı açıkça yer almamaktadır. Ancak doktrinde hâkim olan görüşe göre, bu hükümlerin uygulanabilmesi için, kiralananın devrinden önce kiracıya teslim edilmiş olması şarttır. Bu yönde Acar (n 49) TBK m 310 para 49; Pınar Altınok Ormancı, 'Kira Sözleşmesinin Kurulmasından Sonra Kiralananın El Değiştirmesi: "Satım Kirayı Bozmaz” İlkesinin Sonuçları' (2013) 12 İstanbul Ticaret Üniversitesi Sosyal Bilimler Dergisi 125, 128-29; Gümüş (n 37) 144; Peter Higi ve Christoph Wildisen, Zürcher Kommentar, Obligationenrecht, Vorbemerkungen zum 9. Titel, Art. 253-265 OR (5. Bas1, Schulthess 2019) Art 260-261a para 13; Claire Huguenin, Obligationenrecht Allgemeiner und Besonderer Teil (2. Bas1, Schulthess 2014) para 2979; Roger Weber, 'Art. 261', Heinrich Honsell, Nedim Peter Vogt ve Wolfgang Wiegand (edr), Basler Kommentar - Obligationenrecht I (6. Bası, Schulthess 2015) para 2. 6570 sayılı (mülga) Gayrimenkul Kiraları Hakkında Kanun açısından aynı yönde Özen, 'Kira Konusunun Devri' (n 27) 162-63. Aksi yönde Hürlimann-Kaup (n 25 ) para 572-74; Urban Hulliger ve Peter Heinrich, 'Art. 260-261a', Markus Müller-Chen ve Claire Huguenin (edr), Handkommentar zum Schweizer Privatrecht, Vertragsverhältnisse Teil 1: Innominatkontrakte, Kauf, Tausch, Schenkung, Miete, Leihe (3. Bas1, Schulthess 2016) para 4. Ayrıca bkz İnceoğlu (n 27) 587. Bu yazara göre, kira sözleşmesinin kurulmasından sonra, ancak henüz kiralananın kiracıya teslim edilmeden önce kiralananın mülkiyeti üçüncü kişiye devredilirse ve devreden daha sonra kiralananı kiracıya teslim ederse, devralan kira sözleşmesinin tarafı hâline gelmiş kabul edilmelidir.

51 Türk Borçlar Kanunu'nun 311. maddesinde - İsviçre Borçlar Kanunu’nun 261a maddesinin sözünden kısmen farklı olarak - devralanın 'kiralanan üzerinde kiracının hakkını etkileyen bir ayni hak sahibi' olması ölçütünün getirilmesinin eleştirisi için bkz Gümüş (n 37) 147 .

52 Bu örnekler için bkz Gümüş (n 37) 147; Higi ve Wildisen (n 50) Art 260-261a para 17; Hulliger ve Heinrich (n 50) para 2; Hürlimann-Kaup (n 25) para 625; İnceoğlu (n 27) 606; Öktem Çevik (n 27) 154-61; Roger Weber, 'Art. 261a', Heinrich Honsell, Nedim Peter Vogt ve Wolfgang Wiegand (edr), Basler Kommentar - Obligationenrecht I (6. Bas1, Schulthess 2015) para 1.

53 Hürlimann-Kaup (n 25) para 619.

54 Acar (n 49) TBK m 310 para 21 ve 62; Altınok Ormanc1 (n 50) 129; Gümüş (n 37) 144-45; Higi ve Wildisen (n 50) Art 260261a para 22; Hürlimann-Kaup (n 25) para 576; İnceoğlu (n 27) 588-89; Öktem Çevik (n 27) 40-41 ve 173-74; Weber, 'Art. 261' (n 50) para 4.

55 Higi ve Wildisen (n 50) Art 260-261a para 52; Hulliger ve Heinrich (n 50) para 9; Weber, 'Art. 261' (n 50) para 10. 
yönde bir düzenleme bulunmamaktadır. ${ }^{56}$ Doktrinde savunulan bir görüşe göre, Türk hukukunda da aynı kural kabul edilmelidir. ${ }^{57}$ Her halükârda, devralanın kira sözleşmesini sona erdirmemesi ve bu sözleşmeden doğan borçlarını ihlâl etmesi hâlinde doğan zarardan devreden sorumlu olmayacaktır. ${ }^{58}$ Dolayısıyla, Türk Borçlar Kanunu'nun 310. maddesi ile İsviçre Borçlar Kanunu'nun 261. maddesi, devredeni kira sözleşmesinden (hâkim görüşe göre ileriye etkili olarak) ${ }^{59}$ kurtarmaktadır. $^{60}$ Kira sözleşmesinin tarafının bu şekilde kiracının rızası aranmaksızın değişmesi ve (kira sözleşmesinin erken sona ermesi nedeniyle devredenin sorumluluğu bir yana bırakılırsa) kiracının sadece devralana başvurabilecek olması, onun menfaatlerini ihlâl edebilecek niteliktedir. ${ }^{61}$

Türk Medenî Kanunu'nun 979. maddesinin 3. fikrasının (İsviçre Medenî Kanunu'nun 924. maddesinin 3. fikrasının) bu makalede savunulan görüşe göre taşınmazlara uygulanmaması nedeniyle, Türk Borçlar Kanunu'nun 310. ve 311. maddeleri (İsviçre Borçlar Kanunu'nun 261. ve 261a maddeleri) taşınmaz kiralarında kiracının durumunu iyileştirici sonuç doğurabilir. Ancak, Türk ve İsviçre hukuklarında kira sözleşmesine dair söz konusu hükümler - Alman Medenî Kanunu'nun muadil hükümlerinden farklı olarak - taşınır kiralarına da uygulanmaktadır. ${ }^{62} \mathrm{Bu}$ durum, taşınırın zilyedi olan kiracının - bu makalede savunulan görüşe göre - Türk Medenî Kanunu'nun 979. maddesinin 3. fikrası (İsviçre Medenî Kanunu'nun 924. maddesinin 3. fikrası) uyarınca sahip olacağ1 hukukî durumu kötüleştirebilecek niteliktedir. Taşınır kiralarında kiralananın zilyetliğin havalesi ile devri hâlinde Türk Borçlar Kanunu'nun 310. ve 311. maddeleri yerine Türk Medenî Kanunu'nun 979. maddesinin 3. fikrası uygulansayd1, kiracı kiralananı devralana teslimden yine kaçınabilecekti. ${ }^{63}$ Buna ilave olarak, kiracı kendisi tarafindan kabul edilen kişi (devreden) ile sözleşme ilişkisi içinde kalmaya devam edecekti. Dolayısıyla devreden, kiracıya karşı borçlu ve sorumlu olan kişi olarak kalacaktı. Türk Borçlar Kanunu'nun 310. ve 311. maddelerine göre ise, kiralananın devrinden sonra kiracıya

63 Türk Medenî Kanunu'nun 979. maddesinin 3. fikrası üçüncü kişiye sadece taşınırı teslimden kaçınma yetkisi vermektedir. Üçüncü kişi devralana karşı alacaklı olmadığından, taşınırın elinden çıkması durumunda taşınırı devralandan talep edemeyecektir. Türk Borçlar Kanunu'nun 310. ve 311. maddelerinin kiracıya bu imkânı da vermesi nedeniyle onun lehine olduğu belirtilebilir. Ancak, taşınıra zilyet olan üçüncü kişinin devralan da dahil herkese karşı zilyetliğin korunmasına dair davaları açabilecek olması (TMK 982-984), onun menfaatini büyük ölçüde korumaktadır. Ayrıca, devralanın üçüncü kişinin rızası hilafına onun zilyetliğini sona erdirmesi ve zilyetlik davalarını açmak için öngörülen hak düșürücü sürenin (özellikle bir yıllık sürenin) geçmesi durumunda (TMK 984), devralan - şartları varsa - ahlâka aykırı fiil ile kasten zarar vermesi nedeniyle sorumlu olabilir (TBK 49/II) ve devralanın taşınırı teslim etmek suretiyle aynen tazmine mahkum edilmesi gündeme gelebilir. Açıklanan nedenlerle, Türk Borçlar Kanunu'nun 310. ve 311. maddeleri uyarınca kiracının devralana karşı alacak hakkı sahibi olmasının bahsedilen (sınırlı) avantajları makalede dikkate alınmamıştır.
} 
karşı borçlu ve sorumlu olarak sadece devralan bulunmaktadır. Kiracının bilgisi ve rızası olmaksızın kiralananın devredilebilmesi nedeniyle, söz konusu düzenleme taşınır kiralarında kiracının menfaatlerini ihlâl edebilecek niteliktedir.

Kiraya verenin kiralananın mülkiyetini devralana nakletmesi veya kiralanan üzerinde devralan lehine bazı sınırlı aynî haklar kurması durumunda devralanın kira sözleşmesine kanunen taraf olmasına dair düzenlemeler (TBK 310 ve 311, İsvBK 261 ve 261a), kira sözleşmesi ile genellikle uzun süreli bir ilişki kurulmak istenmesi ile açıklanabilir. ${ }^{64}$ Kiralananın devrinden sonra kira sözleşmesinin tarafları devreden ile kiracı kalır ve (Türk Medenî Kanunu'nun 979. maddesinin 3. fikrası veya İsviçre Medenî Kanunu'nun 924. maddesinin 3. fikrası uyarınca) kiracı bu sözleşmeden doğan savunmaları devralana karşı ileri sürebilirse, devralan eşyayı kullanamayacaktır ve eşyanın kullandırılması nedeniyle kiracıdan kira bedeli talep edemeyecektir. Ayrıca, kira sözleşmesinin sona erip ermemesi, devredenin durumuna ve davranışlarına bağlı olacaktır. Elbette mülkiyetin devri borcunu doğuran sözleşmede devreden ile devralanın bu durumun hukukî sonuçlarını düzenlemeleri mümkündür. Ancak kira sözleşmesinin uzun bir süre devam etmesi ihtimalinin bulunması, özellikle de konut ve çatılı işyeri kiralarında devreden tarafından kanunda öngörülen hâller dışında on yıldan önce feshedilemeyecek olması (TBK 347/I ve 354) nedeniyle, devreden ile devralan arasındaki ilişki karmaşık hâle gelecek ve kiralananın devri fiilen zorlaşacaktır. Bunun yerine, devralanın kira sözleşmesinde devredenin yerini alması hâlinde bu karmaşıklık ortaya çıkmayacaktır. ${ }^{65}$

Kira sözleşmesi ile uzun süreli bir ilişki kurulması özellikle konutlar ve çatılı işyerleri açısından söz konusudur. Kiraya verenin kira sözleşmesini fesih hakkının önemli ölçüde sınırlanması da konut ve çatılı işyerleri için öngörülmüştür (TBK 347/II, 350-352, 354). ${ }^{66}$ Konut veya çatılı işyerini konu almayan belirsiz süreli kira sözleşmelerinin zaten olağan fesih yoluyla sona erdirilmesi mümkündür (TBK 328-330). ${ }^{67}$ Dolayısıyla, yukarıda yapılan açıklamalar, sadece konut ve çatılı işyeri kiralarında devralanın kira sözleşmesinin kanunen tarafı olmasını temellendirebilmektedir. Konut veya çatılı işyeri teşkil etmeyen taşınırlar ${ }^{68}$ açısından bu gerekçe yeterli olmamaktadır. $\mathrm{Bu}$ nedenle, konut veya çatılı işyeri niteliğinde

${ }^{64}$ Karş İnceoğlu (n 27) 573.

${ }^{65}$ Bütün paragraf için karş Martin Häublein, '§ 566 BGB', Münchener Kommentar zum Bürgerlichen Gesetzbuch, Band 5: Schuldrecht - Besonderer Teil II (8. Bas1, CH Beck 2020) para 3. Yazar, üçlü bir ilişkinin kiracı için zor olabileceğini belirtmektedir. Yazara göre, kiralananın devri üzerinde devralan kira sözleşmesinin tarafı haline gelmezse, kiralananın ayıplı hâle gelmesi durumunda, kiracının devredene başvurması ve devredenin de ayıbın giderilmesi için devralanı harekete geçirmesi gerekecektir. Ancak, kiracının taşınmazın dolaysız zilyedi olması nedeniyle, devreden tarafından ayıbın bizzat giderilmesi mümkündür. Ayıbın giderilmesi için masraf yapan devreden, devralan ile arasındaki ilişkinin hükümlerine göre - şartları varsa - devralandan tazminat talep edebilecektir.

66 Taşınmazlar ile ilgili olarak bu yönde İnceoğlu (n 27) 573.

67 Öktem Çevik (n 27) 245 ve 273.

68 Taşınırların (mesela taşınır bir yapının) konut veya işyeri teşkil etmesinin mümkün olduğu ve bu tür bir taşınırın kirasının konut ve çatılı işyeri kirasına dair hükümlere tâbi olduğu belirtilmektedir. Bu yönde Gümüş (n 37) 16; Murat İnceoğlu, Kira $H u k u k u$, (On İki Levha 2014) Cilt II, 11-12 ve 15-16. 
olmayan taşınırların kirasında, kiracının sözleşme ilişkisi içinde olduğu kişinin onun iradesi olmadan değişmesi, irade serbestîsine ölçülülük ilkesine aykırı bir müdahale olarak nitelenebilir. Nitekim kiracıyı koruma amacına taşınır kiralarında Türk Medenî Kanunu'nun 979. maddesinin 3. fikrası ile ulaşılabilecektir. Dolayısıyla Türk Borçlar Kanunu'nun 310. ve 311. maddeleri konut veya çatılı işyeri teşkil etmeyen taşınırların kiralarında kiracının korunması için zorunlu değildir. ${ }^{69}$ Ayrıca, Türk hukukunda - İsviçre hukukundan farklı olarak (İsvBK 261/II-2) - konut veya çatılı işyeri kirası dışındaki kira sözleşmelerinde, devralana sözleşmeyi süresinden önce sona erdirme imkânı da tanınmamıştır. Dolayısıyla, konut veya çatılı işyerini konu alan kira sözleşmesini ihtiyacı nedeniyle süresinden önce feshedebilen devralan (TBK 351), konusunu konut veya çatılı işyeri oluşturmayan süreli kira sözleşmelerinde sürenin sonuna kadar beklemek durumundadır. ${ }^{70}$ Dolayısıyla, konut ve çatılı işyeri teşkil etmeyen taşınırların kirası açısından kiracının menfaatine aykırı sonuçlar doğurabilecek düzenleme, devralanın menfaatlerinin korunmasına da hizmet etmemektedir.

\section{Türk ve İsviçre Doktrinlerinde Hâkim Görüş}

\section{A. Genel Olarak}

Türk ve İsviçre doktrinlerinde hâkim olan görüşe göre, Türk Medenî Kanunu'nun 979. maddesinin 3. fikrası (İsviçre Medenî Kanunu'nun 924. maddesinin 3. fikrası) uyarınca üçüncü kişi tarafindan devralana karşı ileri sürülebilecek savunmalar, sadece aynî hakka ${ }^{71}$ dayanan savunmalardır. Hükmün sözü, üçüncü kişinin devreden ile ilişkisinden doğan şahsî (nisbî) hakkına dayanan savunmaları da devralana karşı ileri sürebileceği anlamını çıkarmaya elverişlidir. Ancak hâkim görüşe göre, üçüncü kişi şahsî (nisbî) hakka dayalı savunmaları devralana karşı ileri süremeyecektir. ${ }^{72} \mathrm{Bu}$ görüş birkaç gerekçeye dayandırılmaktadır.

69 Bu konuda karş Eitel (n 32) 84-85. Yazar, İsviçre Borçlar Kanunu'nun 261. maddesinin (Türk Borçlar Kanunu’nun 310. maddesinin) taşınırlar açısından amacı aşan bir düzenleme teşkil ettiğini belirtmektedir. Yazara göre, İsviçre Medenî Kanunu'nun 924. maddesinin 3. fikrası (Türk Medenî Kanunu'nun 979. maddesinin 3. fikrası) bu makalede de kabul edilen şekilde yorumlansaydı, kanun koyucunun bu aşırı tepkisi engellenebilirdi.

70 Bu durum doktrinde - haklı olarak - eleştirilmektedir. Gümüş (n 37) 142; İnceoğlu (n 27) 575-76.

71 Bu kapsamda ilk olarak sınırlı aynî haklar akla gelmektedir. Ayrıca, taşınır mülkiyetinin devrini geciktirici şarta bağlayan bir mülkiyeti saklı tutma anlaşması yapıldıysa, alıcıya (üçüncü kişiye) ait aynî beklentinin de bu kapsamda olduğu savunulabilir. Bu yönde Ergüne (n 14) para 593; Serozan (n 4) para 54, 202, 507 ve 1182. Bu görüşün açıklanması için ayrıca bkz. Başoğlu (n 22) 82-84; Vardar Hamamcıoğlu (n 23) 258-259. Aksi yönde Halûk Nami Nomer, Beklenen Haklar Üzerindeki Tasarrufların Hukukî Sonuçları (Beta 2002) 154, 157-158. Zürih Yüksek Mahkemesi'nin bir kararında tașınmaz mülkiyetinin kazanılmasına dair aynî bir beklenti olduğu ve İsviçre Medenî Kanunu'nun 924. maddesinin 3. fikrası uyarınca bu aynî beklentinin devralana karşı ileri sürülebilmesi kabul edilmiştir (Obergericht [ZH], II. Zivilkammer, 18.10.1976, para 5). Bu kararın metni için bkz (1977) 76 ZR 141.

72 Akipek ve Akıntürk (n 3) 156; Aybay ve Hatemi (n 4) § 6 para 26; Ergüne (n 14) para 298; Esener ve Güven (n 6) 87; Gümüş (n 37) 138-39; Kemal T Gürsoy, Fikret Eren ve Erol Cansel, Türk Eşya Hukuku (2. Bası, Ankara Üniversitesi Hukuk Fakültesi Yayınları 1984) 92; Hatemi, Serozan ve Arpacı (n 4) 260; Homberger (n 3) Art 924 para 10; Nomer (n 71) 157; Nomer ve Ergüne (n 6) para 149; Oğuzman, Seliçi ve Oktay-Özdemir (n 4) para 384; Ostertag (n 8) Art 924 para 12; Schmid ve Hürlimann-Kaup (n 3) para 174; Serozan (n 4) para 507; Sirmen (n 3) 66; Stark ve Lindenmann (n 5) Art 924 para 37; Steinauer (n 3) para 280; Sutter-Somm (n 5) para 1282; Tuor ve diğerleri (n 6) § 90 para 12; Ünal ve Başpınar (n 3) 162-63. İsviçre Federal Mahkemesi de bu görüştedir (05.12.2008, 5A_699/2008). 
İlk olarak, üçüncü kişinin şahsî hakkını devralana karşı ileri sürebilmesinin hukukumuzda kabul edilen aynî hak - şahsî hak (daha genel olarak: mutlak hak nisbî hak) ayrımına aykırı olduğu ifade edilmektedir. ${ }^{73}$ Nitekim şahsî (nisbî) haklar, aynî (ve diğer mutlak) haklardan farklı olarak, sadece hukukî ilişkinin karşı tarafina ileri sürülebilen haklardır. Ancak, şahsî (nisbî) hakların etki çevresinin kanun koyucu tarafından belli ölçüde genişletilmesi, şahsî (nisbî) hak - mutlak hak ayrımını ortadan kaldırmamakta ve şahsî (nisbî) hakkın aynî hak hâline gelmesine yol açmamaktadır. ${ }^{74}$ $\mathrm{Bu}$ açıdan tapu siciline şerh edilerek etkisi kuvvetlendirilen şahsî (nisbî) haklara işaret edilmesi mümkündür.

Aynî hak - şahsî hak ayrımına dayalı olarak bir sonuca varılması durumunda, Türk Medenî Kanunu'nun 979. maddesinin 3. fikrasının (İsviçre Medenî Kanunu'nun 924. maddesinin 3. fikrasının) neredeyse hiçbir anlamı olmamaktadır. Söz konusu kanun hükmü olmadan da zaten aynı sonuç kabul edilecektir. ${ }^{75}$ Muhtemelen bu eleştiri dikkate alınarak, hâkim görüşün savunulmuş olduğu bir eserde, Türk Medenî Kanunu'nun 979. maddesinin 3. fikrasına (İsviçre Medenî Kanunu'nun 924. maddesinin 3. fikrasına) sadece aynî hak - şahsî hak ayrımından çıkarılamayan anlamlar verilmeye çalışılmaktadır:

- Buna göre, söz konusu hüküm, ilk olarak, devredenin üçüncü kişiye karş1 borcunu ifa etmemesi durumunda üçüncü kişinin hapis hakkını devralana karşı ileri sürmesini sağlamaktadır. Bu sonucun hapis hakkının aynî hak niteliğinde olmasından kaynaklandığı belirtilebilir. Ancak bu açıklama sadece kısmen isabetlidir. Eğer devreden taşınır üzerinde devralana aynî hak kazandırmadan önce üçüncü kişi lehine hapis hakkı doğmuşsa, üçüncü kişinin hapis hakkını devralana karşı da ileri sürebilmesi hakikaten hapis hakkının aynî hak niteliğinde olmasından kaynaklanacaktır. Ancak, devredenin taşınır üzerinde devralana aynî hak kazandırması anında henüz üçüncü kişi hapis hakkını kazanmamışsa, mesela bu an itibariyle devredenin borcu henüz muaccel değilse, borçlu (devreden) ile taşınırın maliki (devralan) farklı kişiler hâline geldiğinden üçüncü kişi (alacaklı) hapis hakkını iktisap edemeyecektir. ${ }^{76}$ Burada aktarılan görüşe göre, Türk Medenî Kanunu'nun 979. maddesinin 3. fikrası (İsviçre Medenî Kanunu'nun 924. maddesinin 3. fikras1) bu tür durumlarda üçüncü kişinin (alacaklının) yine de hapis hakkını kazanmasını sağlamaktadır. ${ }^{77}$

\footnotetext{
3 Homberger (n 3) Art 924 para 10; Ostertag (n 8) Art 924 para 12.

74 Beetschen (n 42) 56-57; Hedinger (n 32) 87 dn 301.

75 Beetschen (n 42) 57-58; Eitel (n 32) 78. Ancak bkz Homberger (n 3) Art 924 para 10. Yazara göre, kanun koyucunun önemli kuralları tekrar etme eğilimi nedeniyle bu durum hükmün yorumu açısından belirleyici değildir.

76 Bu konuda bkz Sirmen (n 3) 741-742: "Hapis hakkı kullanacak olan kimsenin, zilyedi bulunduğu tașınır malların malikine karşı bir alacağının bulunması gerekir (MK 950/I). [...] Hapis hakkı ancak muaccel alacaklar için kullanılabilir. Fakat alacak zilyetliğin kazanıldığı anda değil, hapis hakkının ileri sürüldüğü anda muaccel olmalıdır.” Benzer açıklamalar için bkz Akipek ve Akıntürk (n 3) 860; Nomer ve Ergüne (n 6) para 1324-25; Oğuzman, Seliçi ve Oktay-Özdemir (n 4) para 3761 ve 3765; Schmid ve Hürlimann-Kaup (n 3) para 1925.

77 Stark ve Lindenmann (n 5) Art 924 para 38-39. Aynı yönde Schmid ve Hürlimann-Kaup (n 3) para 174a.
} 
- Söz konusu yazarlara göre, Türk Medenî Kanunu'nun 979. maddesinin 3. fikrası (İsviçre Medenî Kanunu'nun 924. maddesinin 3. fikrası), ikinci olarak, devralanın genel hükümler uyarınca iyiniyetle hak kazanmasına ve bunun sonucunda üçüncü kişinin sınırlı aynî hakkını kaybetmesine (veya onun sınırlı aynî hakkının iyiniyetle hak kazanan devralanın sınırlı aynî hakkına göre arka sırada kalmasına) engel olmaktadır. ${ }^{78}$ Ancak, bu durumda, taşınırın üçüncü kişinin dolaysız zilyetliğinde olması nedeniyle, taşınır üzerinde üçüncü kişinin sınırlı aynî hakkı olduğunu bilmesi dürüstlük kuralı uyarınca devralandan beklenebilecektir. Dolayısıyla, devralan iyiniyetli olduğunu ileri süremeyecektir (TMK 3/II) ve iyiniyetle hak kazanması söz konusu olmayacaktır. ${ }^{79} \mathrm{Bu}$ konuda özel bir düzenleme yapılmasına gerek bulunmamaktadır.

Hâkim görüşe göre, üçüncü kişi zilyedin şahsî (nisbî) hakka dayanan savunmaları devralana karşı ileri sürülmesi kabul edilirse, zilyetliğin şahsî (nisbî) hakların etkilerini kuvvetlendirdiğinin kabulü gerekir ${ }^{80}$ ve Türk/ İsviçre hukuklarında zilyetliğin böyle bir işlevi bulunmamaktadır. ${ }^{81}$ Ancak, zilyetliğin şahsî (nisbî) hakları (dolaylı olarak) kuvvetlendirme etkisinin olup olmaması hakkında a priori bir kabulden hareket ederek kanun hükümlerinin yorumlanması yöntem olarak eleştiriye açıktır. Aksine, kanun hükümlerinin yorumlanması sonucunda belirlenen kurallardan hareket ederek zilyetliğin işlevlerini tespit etmek yöntem olarak daha uygun gözükmektedir. Nitekim, Türk doktrininde bir yazar, burada incelenen mesele açısından hâkim görüşe katılmakla beraber, zilyetliğin korunmasına ve taşınır davasına dair hükümlere dayalı olarak, zilyetliğin nisbî alacak haklarını dolaylı olarak kuvvetlendirdiğini ifade etmektedir. ${ }^{82}$ Ayrıca, Alman doktrininde de, Türk Medenî Kanunu'nun 979. maddesinin (İsviçre Medenî Kanunu'nun 924. maddesinin) 3. fikrasına benzer bir düzenleme içeren Alman Medenî Kanunu'nun § 986 hükmünün 2. fikrasına

\footnotetext{
8 Stark ve Lindenmann (n 5) Art 924 para 41. Ayrica bkz Homberger (n 3) Art 924 para 11; Ostertag (n 8) Art 924 para 12; Serozan (n 4) para 58, 506, 1161 ve 1488. Bu yazarlar, devralanın iyiniyetli olması hâlinde bile üçüncü kişinin sınırlı aynî hakkını devralana karşı ileri sürebileceğini belirtmektedir.

79 Aksi yönde Nomer (n 71) 154. Bu yazara göre, üçüncü kişinin dolaysız zilyet olması durumunda iyiniyet şartının gerçekleşmesi zordur; ancak imkânsız değildir. Bu görüşü desteklemek için, devralanın üçüncü kişiyi saklayan (vedia alan) sanması iyiniyetli olmasına örnek olarak gösterilebilir. Bu yönde Stark ve Lindenmann (n 5) Art 924 para 41. Ancak, yazarların aynı paragrafta yer alan ifadelerine göre, devredenin dolaylı zilyet olması nedeniyle, devralanın mülkiyeti nakledilen taşınır üzerinde üçüncü kişinin sınırlı aynî hakkı olmadığını kabul etmesi hâl ve şartlara uygun olmayacaktır.

80 Oğuzman, Seliçi ve Oktay-Özdemir (n 4) para 384 dn 115; Ünal ve Başpınar (n 3) 162.

81 Oğuzman, Seliçi ve Oktay-Özdemir (n 4) para 384; Ergüne (n 14) para 298; Nomer ve Ergüne (n 6) para 149.

${ }_{82}$ Serozan (n 4) para 112-14. Aynı yönde Hatemi, Serozan ve Arpacı (n 4) 18-19.
} 
dayalı olarak, zilyetliğin nisbî hakları kuvvetlendirme ${ }^{83}$ işlevinin olduğu kabul edilmektedir. $^{84}$

Hâkim görüşü savunan bazı yazarlar, Türk/İsviçre hukukunda şahsî (nisbî) hakların kuvvetlendirilmesinin sadece tapu siciline şerh verilmekle mümkün olduğunu ve tapu siciline şerh edilme dışında bir yolla şahsî (nisbî) hakların etkisinin kuvvetlendirilemeyeceğini belirtmektedir. ${ }^{85}$ Ancak Alman hukuku ile bir karşılaştırma, böyle bir yorumun zorunlu olmadığını göstermektedir. Alman Medenî Kanunu'nun $\S 883$ hükmü uyarınca da bazı şahsî hakların tapu siciline şerh edilmesi mümkündür ve şahsî hakların şerhedilmesi onların etkilerini kuvvetlendiren hâllerden biri -hatta en önemlisi - olarak kabul edilmektedir. ${ }^{86}$ Dolayısıyla, şahsî hakkın etkisinin tapu siciline şerh verilerek kuvvetlendirilebilmesi, şahsî hak sahibinin zilyet olması sonucunda da hakkının dolaylı olarak kuvvetlendiğinin kabulüne ${ }^{87}$ engel olarak görülmemektedir.

Türk ve İsviçre doktrinlerinde hâkim görüşü destekleyen bir husus, İsviçre Medenî Kanunu Öntasarısı'nı hazırlayan Eugen Huber'in öntasarının gerekçesinde açıkça bu görüşü kabul etmiş olmasıdır. ${ }^{88}$ Ancak Eugen Huber, İsviçre parlamentosunun halk temsilcilerinden oluşan kanadında (Nationalrat, Conseil national) hukuk

83 Alman doktrininde bu tür durumlar için 'nisbî hakların aynîleşmesi' (Verdinglichung obligatorischer Rechte) kavramı kullanılmaktadır. Nisbî hakkın aynîleşmesi, nisbî (şahsî) hakkın aynî hak hâline gelmesi anlamına gelmemektedir. Bu kavram, nisbî (şahsî) hakkın aynî hakların sadece bazı özelliklerini kazanmasını ifade etmektedir. Ancak, söz konusu hak, aynî hak olmak için gereken bütün özelliklere sahip olmamaktır. Aksi takdirde, söz konusu hakkı zaten doğrudan aynî hak olarak nitelendirmek gerekecektir. Bu konuda bkz Claus-Wilhelm Canaris, 'Die Verdinglichung obligatorischer Rechte', Horst Heinrich Jacobs ve diğerleri (edr), Festschrift für Werner Flume zum 70. Geburtstag (Verlag Dr. Otto Schmidt KG 1978) 371, 372; Waltermann (n 1) 525. Alman doktrininde zilyetlik, nisbî hakların aynîleşmesi sonucunu doğuran en önemli araçlardan biri olarak kabul edilmektedir; ancak nisbî hakların aynîleşmesi için zilyetlik ne zorunludur ne de yeterlidir. Canaris (n 83) 380.

${ }_{84}$ Baur ve Stürner (n 33) § 6 para 4. Ayrıca bkz Harm Peter Westermann, Karl-Heinz Gursky ve Dieter Eickmann, Sachenrecht (8. Bası, CF Müller 2011) § 7 para 5. Bu yazarlar, alacaklının zilyetlik sayesinde aynî haklara benzer mutlak bir koruma elde ettiğini belirtmektedir.

85 Ünal ve Başpınar (n 3) 162.

86 Canaris (n 83) 381.

87 Alman hukukunda bu yönde Wilhelm Weimar, 'Die Erhaltungsfunktion des Besitzes gem. § 986 Abs. 2 BGB' [1982] JR 364.

88 Markus Reber ve Christoph Hurni (edr), Berner Kommentar, Kommentar zum Schweizerischen Privatrecht, Materialien zum Zivilgesetzbuch, Die Erläuterungen von Eugen Huber, Band II (Stämpfli 2007) para 2077: 'Behält der Dritte die Sache, so ist zweierlei zu ordnen: Sein Besitz im Namen des neuen Berechtigten beginnt mit der Mitteilung dieses Vorganges durch den Geber, und die Rückleistungspflicht darf gegenüber dem neuen Berechtigten nicht verschärft sein, so dass also der Dritte die Rückgabe dem Empfänger aus den gleichen Gründen verweigern darf, wie dem Geber. Doch ist dies natürlich nur auf die dingliche Berechtigung zu beziehen. Steht der Mieter dem Vermieter gegenüber, so hat er gegen diesen, insofern nicht eine Vormerkung im Grundbuch [...] vorliegt, nur einen persönlichen Anspruch, der sich gegenüber einem neuen Eigentümer nicht in einen dinglichen verwandeln wird. Der Dritte vermag die Herausgabe also nur zu verweigern aus Gründen, die er als dinglich wirkende jedermann oder als persönlich wirkende gerade der Person des Empfängers gegenüber geltend machen kann. Retinieren darf er sie, wie wenn noch der Geber ihm gegenüber stände.' (Üçüncü kişi eşyayı elinde bulundurursa, ikili bir düzenleme yapılmalıdır: Onun yeni hak sahibi için zilyet olması, bu işlemin [zilyetliğin havalesi işleminin] devreden tarafindan [ona] bildirimi üzerine başlar ve [onun] geri verme yükümlülügü yeni hak sahibine karşı ağırlaşmamalıdır; öyle ki, üçüncü kişi devredene karşı ileri sürebildiği sebeplere dayalı olarak devralana [eşyayı] geri vermeden kaçınabilir. Ancak bu doğal olarak sadece aynî hak sahipliğine ilișkindir. Kiracı kiraya verenin karșısında yer alıyorsa, tapu siciline şerh verilmesi söz konusu olmadığı takdirde, [kiracı] [kiraya verene] karşı sadece şahsî hak sahibidir ve bu hak yeni malike karşı aynî hakka dönüşmez. Yani üçüncü kişi sadece aynî etkili olarak herkese karşı ileri sürülebilen veya şahsî etkili olarak tam da devralana karşı ileri sürülebilen sebeplere dayalı olarak [eşyayı] vermeden kaçınabilir. Hapis hakkını sanki karşısında hâlen devreden varmış gibi kullanabilir.) (Tercüme bu makalenin yazarına aittir.) 
komisyonunun Almanca raportörü olarak genel kurula hitaben konuşmasında bu konuda özel olarak herhangi bir açıklamaya yer vermemiştir. ${ }^{89}$ Buna mukabil, hukuk komisyonunun Fransızca raportörü olan Virgile Rossel, genel kurula hitaben konuşmasında, özel bir hukukî ilişkiye dayalı olarak zilyet kalmaya devam eden üçüncü kişinin devredene karşı ileri sürebildiği bütün savunmaları devralana karşı da ileri sürebilmesini açıklarken, özel hukukî ilişkiye örnek olarak kira ve kullanım ödüncü (ariyet) sözleşmelerini vermiştir. ${ }^{90}$ İsviçre parlamentosunun iradesinin oluşmasında iki raportörün genel kurula yönelik açıklamalarının da etkili olduğunun dikkate alınırsa, tarihî yorum aracının aslında İsviçre (ve Türk) doktrininde hâkim olan görüşten ziyade bu makalede savunulan görüşü desteklediği ifade edilebilir. ${ }^{91}$

Son olarak belirtilmelidir ki, doktrinde bazı yazarlar tarafindan kullanılan ifadeler, aynî hak ile şahsî hakkın birbirine karşı ileri sürülmesi durumunda, aynî hakkın üstün olduğu yönünde anlaşılabilecek niteliktedir. ${ }^{92}$ Aynî hakları (genel olarak mutlak hakları) şahsî (nisbî) haklardan daha kuvvetli kılan husus, aynî hakların herkese karşı ileri sürülebilmesidir. Şahsî (nisbî) haklar ise sadece belirli kişi veya kişilere ileri sürülebilmektedir. Ancak aynî hak sahibine karşı ileri sürülebilen bir şahsî (nisbî) hak mevcutsa, ${ }^{93}$ aynî hakkın şahsî hakka üstün olması söz konusu değildir. Bu durum, istihkak davasına dair düzenlemeden görülebilmektedir. Davacının aynî hakkına dayalı olarak istihkak davası açması durumunda, davalı davacıya karşı bir şahsî hak sahibi ise haksız zilyet değildir ve davanın reddi gerekir. ${ }^{94}$

91 Karş Eitel (n 32) 77. Yazara göre, kanunlaştırma sürecine dair kaynaklar hâkim görüşü açıkça destekler nitelikte değildir.

92 Mesela bkz Esener ve Güven (n 6) 53: 'Esas itibariyla aynî hak ile nisbî hak arasında uyuşmazlık çıktığı zaman aynî hakka itibar olunur.' Aslında yazarlar, aynî hak sahibinin aynı zamanda şahsî (nisbî) hakkın muhatabı (borçlu) olması durumunda, şahsî (nisbî) hakkın aynî hakka üstün olduğunu belirtmektedir. Ancak yazarlar, bu durumu '[a]ynî hak ile nisbî hakkın çatışması halinde aynî hakkın üstün tutulacağı prensibinin bir [...] istisnası' olarak kabul etmektedir (ibid).

93 Türk ve İsviçre doktrinlerinde savunulan bir görüşe göre, eşyaya zilyet olma yetkisi veren (sınırlı aynî veya şahsî) hakkın sahibi (mesela kiracı), malik ile arasındaki ilișkinin (mesela kira sözleșmesinin) hükümlerine aykırı davranmaksızın, başka bir kişiye (mesela alt kiracıya) eşyaya zilyet olma yetkisi veren bir şahsî hak tanımış ve bu kişiye (alt kiracıya) eşyanın zilyetliğini devretmișse, söz konusu kiși (alt kiracı) haksız zilyet değildir ve ona karșı malik tarafından istihkak davası açılamaması gerekir. Bu durumda, davalı (alt kiracı) aslında davacıya (malike) karşı ileri sürülebilen bir şahsî hak sahibi değildir. Davalının (alt kiracının) şahsî hakkı, sadece onunla borçlandırıcı işlem (alt kira sözleşmesi) yapan kişiye (kiracıya) ileri sürülebilir. Alman Medenî Kanunu'nun $§ 986$ hükmünün ilk fikrasında, bahsedilen durumda olan davalının (mesela alt kiracının) eşyayı davacıya (malike) iadeden kaçınabileceğine dair açık bir düzenleme vardır. Türk ve İsviçre hukuklarında bu tür açık bir kanun hükmü olmamasına rağmen doktrinde aynı sonuç kabul edilmektedir. Bu yönde Oğuzman, Seliçi ve Oktay-Özdemir (n 4) para 1141; Sirmen (n 3) 275; Wolfgang Wiegand, 'Art. 641', Heinrich Honsell, Nedim Peter Vogt ve Thomas Geiser (edr), Basler Kommentar - Zivilgesetzbuch II (5. Bası, Helbing Lichtenhahn 2015) para 50. Malike karș eşyaya zilyet olma yetkisi veren hakkın sahibi (mesela kiracı), başka birini eşyaya zilyet kılma yetkisine sahip değilse (mesela kira sözleşmesinde alt kira sözleşmesi yapılması yasaklanmışsa), söz konusu hakkın sahibinden (kiracıdan) şahsî hak elde eden kişi (alt kiracı) malike karşı haklı zilyet değildir. Bu konuda bkz Ertaş (n 4) para 977. Bu durumda, Alman Medenî Kanunu'nun § 986 hükmünün ilk fikrasında düzenlenmiş olduğu gibi, malikin eşyanın haklı zilyede (kiracıya) iadesini talep edebileceği; bu kişinin iadeyi kabul etmemesi durumunda ise, malikin kendisine iadeyi talep edebileceği belirtilmektedir. Bu yönde Ruth Arnet, 'Art. 641', Peter Breitschmid ve Alexandra Jungo (edr), Handkommentar zum Schweizer Privatrecht, Sachenrecht (3. Bas1, Schulthess 2016) para 36; Wiegand (n 93) para 50.

94 Bu durumda, davalının şahsî hak sahibi olduğu dava dosyasından anlaşılabiliyorsa, hâkimin bu hakkı re'sen dikkate alıp alamayacağı tartışmalıdır. Bu konudaki görüşler hakkında ayrıntılı açıklamalar için bkz Burak Özen, Haksız Zilyetlikte İade (Beta 2003) 9-28. 


\section{B. Kira Sözleşmesine Dair Özel Hükümler Hakkında Değerlendirmeler}

Türk ve İsviçre doktrinlerinde hâkim olan görüşü savunanlar, kira sözleşmesine dair hükümlerin kendi görüşlerini desteklediğini kabul etmektedir.

\section{a. 818 Sayılı Borçlar Kanunu'nun ve İsviçre Borçlar Kanunu'nun Önceki Hükümleri Hakkında Değerlendirme}

Bu kapsamda, ilk olarak, 818 sayılı (önceki) Borçlar Kanunu'nun 254. maddesi ve İsviçre Borçlar Kanunu'nun 01.07.1990 tarihinden önceki (ilk) hâli ile 259. maddesi ele alınmalıdır. Bu maddelerin ilk fikrasına göre, kira sözleşmesinin kurulmasından sonra kiralananın mülkiyetinin devredilmesi durumunda, devralan bu yönde irade beyanında bulunmadıkça kira sözleşmesinden doğan bir borç altına girmemektedir; ${ }^{95}$ dolayısıyla da kiracı kira sözleşmesinden doğan borcun ifasını ondan talep edemez. Kiracı sadece devredene karşı hak ileri sürebilecektir. Ancak, maddenin ikinci fikrasına göre, kiralanan taşınmaz ise, devralan, kira sözleşmesinin feshedilmesi mümkün olan ilk ana kadar, kiralananın kiracı tarafindan kullanılmasına katlanmakla yükümlüdür. ${ }^{96}$

Doktrinde hâkim olan görüşe göre, kiralananın devrine dair açıklanan hüküm, üçüncü kişinin eşyaya zilyet olmasının en önemli hâli olan kira ilişkilerinde, kiracının kira sözleşmesinden doğan alacak hakkını devralana karşı ileri sürememesini öngörerek, aynî hak - şahsî hak ayrımına dayalı olarak hukukî sonuçların belirlenmesi düşüncesini teyit etmektedir. ${ }^{97}$ Dolayısıyla, bu hüküm, zilyetliğin havalesinde üçüncü kişinin şahsî hakka dayanan savunmaları devralana karşı ileri sürememesi yönündeki görüşü desteklemektedir. ${ }^{98} \mathrm{Bu}$ durumda, kanun koyucunun genel kuralı neden kira sözleşmesine dair özel bir hükümde tekrar etmeye gerek gördüğünün sorulması mümkündür. Hâkim görüşü savunanlar tarafindan bu soruya verilebilecek cevap, kira sözleşmesinin önemi nedeniyle kanun koyucunun bu sözleşme ile ilgili düzenlemeler arasında genel kuralı yansıtan bu hükme yer vermiş olabileceğidir. ${ }^{99}$ Ayrıca, kanun koyucunun taşınmazlar ile ilgili (sınırlı) bir istisna öngörmeden önce, genel kuralı yansitan düzenlemeye yer vermeyi yararlı görmüş olabileceğinin de ileri sürülmesi mümkündür. ${ }^{100}$

\footnotetext{
95 Bu konuda bkz yukarıda dn 37.

96 Bu konuda bkz yukarida dn 38.

97 Homberger (n 3) Art 924 para 10; Ostertag (n 8) Art 924 para 12.

98 Akipek ve Akıntürk (n 3) 156.

99 Karş Homberger (n 3) Art 924 para 10. Yazar, kanun koyucunun önemli kuralları tekrar etme eğilimine işaret etmektedir.

100 Bucher (n 32) 171. Yazara göre, İsviçre Borçlar Kanunu'nun 01.07.1990 tarihinden önceki (ilk) hâli ile 259. maddesinde 'kira satımı bozar' kuralının öngörülmüş olmasının nedeni, bu ilkenin kanunda düzenlenmesine ihtiyaç duyulması değildir. Söz konusu kural temel ilkelerden zaten çıkarılabilmektedir. Kanun koyucunun söz konusu hükmü getirmesinin amacı, bu kuralın taşınmazlar açısından belli ölçüde zayıflatılmasıdır.
} 


\section{b. 6098 Sayılı Türk Borçlar Kanunu'nun ve İsviçre Borçlar Kanunu'nun Yeni Hükümleri Hakkında Değerlendirme}

6098 say1lı Türk Borçlar Kanunu'nun 310. maddesine ve İsviçre Borçlar Kanunu'nun (yürürlükte olan) 261. maddesine göre, kira sözleşmesinin kurulmasından sonra kiraya veren kiralananın mülkiyetini devrederse, devralan kira sözleşmesinde devredenin yerini almaktadır. Hâkim görüşü savunan yazarlara göre, kanun koyucu bu hükmü sevk ederek üçüncü kişinin (kiracının) devredenle (kiraya verenle) olan sözleşmesinden doğan bir şahsî hakkını devralana karşı da ileri sürebilmesi imkânını yaratmıştır. ${ }^{101}$ Söz konusu hüküm ile özel bir düzenleme yapılmasına ihtiyaç duyulması, Türk Medenî Kanunu'nun 979. maddesinin 3. fikrası (İsviçre Medenî Kanunu'nun 924. maddesinin 3. fikrası) uyarınca üçüncü kişinin (kiracının) alacak hakkına dayanan savunmaları devralana karşı ileri süremeyeceğini göstermektedir. ${ }^{102}$

\section{3. İsviçre Doktrininde Savunulan Yeni Görüş̧}

\section{A. Görüşün Açıklanması}

İsviçre doktrininde savunulan yeni görüşe göre, zilyetliğin havalesinin üçüncü kişiye bildirilmesi üzerine, devreden ile üçüncü kişi arasındaki hukukî ilişkide devredenin yerini kanunen devralan alır (İsvMK 924/II, TMK 979/II). ${ }^{103}$ Üçüncü kişinin kanunen gerçekleşen bu taraf değişikliğine etkisi yoktur. ${ }^{104}$ Üçüncü kişinin devredenle olan ilişkisinden doğan şahsî hakka dayanan savunmaları devralana karşı ileri sürebilmesi (İsvMK 924/III, TMK 979/III), devralanın bu ilişkinin yeni tarafı olmasından kaynaklanmaktadır. Bu görüşü savunan Happel'e göre, İsviçre Medenî Kanunu'nun 924. maddesinin (Türk Medenî Kanunu'nun 979. maddesinin) bütün fikralarının birbirleriyle uyumlu olarak yorumu ancak bu şekilde mümkün olmaktadır ${ }^{105}$ ve maddenin son fikrası bu sayede sözüne uygun şekilde anlaşılabilmektedir. ${ }^{106}$

101 Oğuzman, Seliçi ve Oktay-Özdemir (n 4) para 384.

102 Oğuzman, Seliçi ve Oktay-Özdemir (n 4) para 384-85. Ayrıca bkz Sirmen (n 3) 66.

103 Ernst (n 5) para 10 ve 16; Happel (n 5) 65-66. Bu görüşün ilk olarak Stark tarafindan savunulmuş olduğu belirtilmektedir (Happel (n 5) 69). Stark, Berner Kommentar'ın 2001 basısında İsviçre (ve Türk) doktrininde hâkim olan görüşe katılmaktaydı (Emil W Stark, Kommentar zum schweizerischen Privatrecht, Band IV: Das Sachenrecht, 3. Abteilung: Besitz und Grundbuch, 1. Teilband: Der Besitz, Art. 919-941 ZGB (3. Bas1, Bern 2001) Art 924 para 22 vd ve 37); ancak Basler Kommentar'ı 2003 basısında yeni görüşü savunmuştur (Emil W Stark, 'Art. 924 ZGB', Heinrich Honsell, Nedim Peter Vogt ve Thomas Geiser (edr), Basler Kommentar - Zivilgesetzbuch II (2. Bas1, Helbing Lichtenhahn 2003) para 10 vd). Basler Kommentar'ın 2014 basısında İsviçre Medenî Kanunu'nun 924. maddesini şerh eden Ernst, Stark tarafından ileri sürülen yeni görüşü savunmaya devam etmiştir (Ernst (n 5) para 10 vd.). Ernst, bu görüşün Happel tarafından ayrıntılı olarak gerekçelendirilmiş olduğunu belirtmektedir (Ernst (n 5) para 10). Berner Kommentar'da Stark tarafindan kaleme alınan şerhin Lindenmann tarafından güncellenen 2016 basısında ise hâlen hâkim görüş savunulmaktadır (Stark ve Lindenmann (n 5) Art 924 para 22 vd ve 37).

104 Ernst (n 5) para 16; Happel (n 5) 66-67.

105 Happel (n 5) 70.

106 Happel (n 5) 69. 
Bu görüşü savunanların hareket noktası, dolaysız zilyedin ${ }^{107}$ başka bir kişinin zilyetlik aracısı olması için söz konusu iki kişi arasında (geçerli olsun veya olmasın) ${ }^{108}$ özel bir hukukî ilişki bulunmasının zorunlu olmasıdır ${ }^{109}$ (İsvMK 924/I, TBK 979/I). ${ }^{110}$ Hukukî ilişkinin borçlandırıcı bir işlemden doğması zorunlu değildir; kanundan doğan bir ilişki olması da mümkündür. Ancak, iki kişi arasında herhangi bir hukukî ilişki olmaksızın bir kişinin öteki kişinin zilyetlik aracısı olması mümkün değildir. ${ }^{111}$ Eşyanın dolaysız zilyet tarafından neticede dolaylı zilyede iadesinin kararlaştırılmış olması durumunda taraflar arasında bir hukukî ilişki (hiçbir sözleşme tipine uymuyorsa isimsiz bir sözleşme) meydana gelir. ${ }^{112}$ Zilyetliğin havalesinin üçüncü kişi açısından hüküm doğurması, üçüncü kişinin devreden yerine devralan için zilyetlik aracısı olması sonucunu doğurur. Üçüncü kişi ile devralan arasında ayrı bir hukukî ilişki olmaması nedeniyle, burada açıklanan görüşü savunanlara göre üçüncü kişi ile devreden arasındaki ilişkinin kanunen devralana geçtiğini kabul etmek zorunlu olmaktadır. ${ }^{113}$ Üçüncü kişi ile devreden arasındaki hukukî ilişki devralana geçmiş olduğundan üçüncü kişinin bu ilişkiden doğan hakları ve borçları da artık sadece devralana yönelik haklar ve borçlardır. ${ }^{114}$

Zilyetliğin havalesi ile devreden tarafından devralana mülkiyetin geçirilmesi yerine ona bir rehin hakkı kazandırılması durumunda, burada açıklanan görüşü savunan Happel'e göre daha farklı bir hukukî durum ortaya çıkmaktadır. Nitekim bu durumda üçüncü kişi ile devreden arasındaki hukukî ilişkide devredenin

107 Zilyetlik aracısının dolaysız zilyet olması zorunlu değildir. Kendisi dolaylı zilyet olan bir kişinin başka bir kişi için zilyetlik aracısı olması ve ona da dolaylı zilyet kazandırması mümkündür. Mesela, intifa hakkı konusu olan bir eșyanın intifa hakkı sahibi tarafından ödünç verilmesi ve ödünç alana teslim edilmesi durumunda, intifa hakkı sahibi dolaylı zilyettir ve malik için zilyetlik aracısı olması nedeniyle ona da dolaylı zilyetlik kazandırmaktadır. Ancak, anlatımda kolaylık olması için, metnin ilerleyen kısımlarında zilyetlik aracısının dolaysız zilyet olması ihtimali dikkate alınacaktır.

108 Dolaysız zilyet ile dolaylı zilyet arasındaki hukukî ilişki geçersiz olsa da, bu kişiler aralarında geçerli bir hukukî ilişki varmış gibi davranıyorlarsa, dolaylı zilyetlik söz konusu olur. Nicolas Fuchs, Die Besitzesschutzklagen nach Art. 927 ff. ZGB (Dike 2018) para 75; Homberger (n 3) Art 920 para 11; Stark ve Lindenmann (n 5) Art 924 para 15.

109 Bu düşünce özellikle Alman hukukuna ve doktrinine dayandırılabilir. Alman Medenî Kanunu'nun dolaylı zilyetlik ile ilgili § 868 hükmüne göre, bir kişi (dolaysız zilyet), bir süre boyunca eşyanın zilyedi olma hakkı veren veya borcu yükleyen bir ilişkiye dayalı olarak eşyaya zilyet olmuşsa, bu ilişkinin diğer tarafinda olan kişi de zilyettir (dolaylı zilyettir). Alman doktrininde bu hukukî ilișki 'zilyetlik aracılığı ilișkisi' (Besitzmittlungsverhältnis) olarak adlandırılmaktadır. İsviçre doktrininde 'zilyetlik aracılığı ilişkisi' kavramı sadece bazı yazarlar tarafından kullanılmaktadır. Bu yönde Fuchs (n 108) para 75; Stark ve Lindenmann (n 5) Art 924 para 14 vd. Türk doktrininde ise, 'zilyetlik aracılı̆̆ı ilișkisi' kavramı kullanılmamaktadır. Bu nedenle, bu makalede söz konusu kavram yerine ‘özel hukukî ilişki’ kavramı kullanılacaktır.

110 Ernst (n 5) para 11; Fuchs (n 108) para 75; Happel (n 5) 66. Ayrıca bkz Arnet ve Eitel (n 11) para 3. İsviçre doktrininde savunulan bir görüşe göre, zilyetliğin havalesi için üçüncü kişi ile devreden arasında özel bir hukuki ilişki olmasına gerek yoktur. Bu görüşü savunan yazarlara göre, kanunun sözü aksine anlaşılabilse de, özel hukukî ilişsi şartı sadece hükmen teslim için aranmaktadır. Bu yönde Stark ve Lindenmann (n 5) Art 924 para 18. Ancak yazarlar, eserlerinin başka bir yerinde, dolaysız zilyedin borçlandırıcı işlemden doğan bir şahsî hakka veya bir sınırlı aynî hakka dayalı olarak eșyaya zilyet olması nedeniyle dolaysız zilyet ile dolaylı zilyet arasında bir hukukî ilişki olduğundan bahsetmektedir. Stark ve Lindenmann (n 5) Art 924 para 36. Zilyetliğin havalesinde üçüncü kişi ile devreden arasında özel hukukî ilişki şartını aramayan görüşün eleştirisi için bkz Happel (n 5) 64-65.

111 İsviçre Medenî Kanunu’nun 924. maddesinin 3. fikrasının (Türk Medenî Kanunu’nun 979. maddesinin 3. fikrasının) yorumu açısından hâkim görüşe katılmakla beraber dolaylı zilyetlik açısından bu yönde bkz Sutter-Somm (n 5) para 1218. Hükmen teslim açısından bu yönde Stark ve Lindenmann (n 5) Art 924 para 16.

112 Ernst (n 5) para 12

113 Ernst (n 5) para 11; Happel (n 5) 66.

114 Borçlar açısından Ernst (n 5) para 13. 
yerini devralanın alması (kanunen ilişkinin tarafının değişmesi) uygun bir çözüm olmamaktadır. Bu nedenle Happel, zilyetliğin havalesinin bildirimi üzerine üçüncü kişi ile devralan arasında yeni ve ayrı bir hukukî ilişkinin kanunen meydana geldiğini kabul etmektedir. ${ }^{115}$

Aç1klanan görüşe göre, kira sözleşmesine dair özel düzenleme (İsvBK 261/I, TBK 310) olmasaydı bile, kira sözleşmesinin kurulmasından ve kiralananın kiracıya tesliminden ${ }^{116}$ sonra kiralananın devri hâlinde, İsviçre Medenî Kanunu'nun 924. maddesinin 3. fikrası (Türk Medenî Kanunu'nun 979. maddesinin 3. fikras1) uyarınca devralanın kira sözleşmesinin tarafı olması sonucu doğacaktı. ${ }^{117} \mathrm{Bu}$ görüş kabul edilse bile, kira sözleşmesine dair düzenlemelerin yine de bazı açılardan hukukî durumu değiştirdikleri kabul edilebilirdi. İlk olarak, kira sözleşmesinin yeni tarafı olan devralana kira sözleşmesini sona erdirmek için ek imkânlar tanınmasına dikkat çekilebilirdi (İsvBK 261/II, Türk hukukunda sadece konut çatılı işyeri kiraları açısından TBK 351). Ayrıca, devralanın kira sözleşmesini bu şekilde sona erdirmesi durumunda devredenin sorumluluğuna dair hükme işaret edilebilirdi (İsvBK 261/ III). ${ }^{118}$ Son olarak, İsviçre Medenî Kanunu'nun 924. maddesinin 3. fikrasının (Türk Medenî Kanunu'nun 979. maddesinin 3. fikrasının) sadece taşınırlar açısından uygulanacağının kabulü durumunda, kira sözleşmesine dair hükümlerin taşınmazlar açısından sözleşmenin kanunen devri sonucunu doğurduğu belirtilebilirdi.

\section{B. Görüşün Eleştirisi}

Üçüncü kişinin devralan için zilyetlik aracısı olması, üçüncü kişi ile devralan arasında kanundan doğan bir hukukî ilişki meydana geldiğinin kabulü ile mümkündür. Dolayısıyla, üçüncü kişi ile devreden arasındaki hukukî ilişkinin devredenden devralana geçtiğinin kabulü zorunlu değildir. Nitekim Happel da, devralana rehin hakkı kazandırılması durumunda üçüncü kişi ile devralan arasında kanundan doğan bir hukukî ilişki meydana geldiğini ifade etmektedir. Aynı sonucun devralana mülkiyet hakkı kazandırılması durumunda da kabulüne herhangi bir engel bulunmamaktadır.

Üçüncü kişi ile olan hukukî ilişkinin devredenden devralana geçmesi üçüncü kişiyi koruyan bir düzenleme olarak açıklanmaktadır. ${ }^{119} \mathrm{Bu}$ görüşü savunanlara göre, zilyetliğin havalesinin üçüncü kişiye bildirilmesi üzerine üçüncü kişi ile olan hukukî ilişkide devredenin yerini devralanın aldığının kabul edilmemesi durumunda,

115 Happel (n 5) 74-79.

116 İsviçre Borçlar Kanunu'nun 261. maddesinin ilk fikrasının ve Türk Borçlar Kanunu'nun 310. maddesinin uygulanması için kiralananın kiracıya tesliminin şart olup olmadığına dair tartışma yukarıda açıklanmıştı. Bkz yukarıda dn 50. İsviçre Medenî Kanunu'nun 924. maddesinin 3. fikrasının ve Türk Medenî Kanunu’nun 979. maddesinin 3. fikrasının kiralananın devrine uygulanması gündeme gelirse, kiralananın kiracıya teslim edilmiş olması şart olacaktır. Bunun nedeni, zilyetliğin havalesinin söz konusu olabilmesi için kiracının kiralanana zilyet olmasının gerekmesidir.

117 Happel (n 5) 69.

118 Türk hukuku için bkz yukarıda dn 57.

119 Ernst (n 5) para 13. 
üçüncü kişi sadece aynî hak sahibi olmasına dayanan savunmaları devralana karş1 ileri sürebilecektir; ${ }^{120}$ yani Türk ve İsviçre doktrinlerinde hâkim olan görüşün kabulü gerekecektir. Ancak, bu şekilde bir yorum yapılmasının zorunlu olmadığı önceki kısımlarda (bu makalede savunulan görüş açıklanırken) gösterilmiştir.

Üçüncü kişinin haklarını devreden yerine sadece devralana karşı ileri sürebilmesi ve devralana karşı borçlu olması onun menfaatine olmayabilir. Burada açıklanan görüşü savunanlar, üçüncü kişinin devralan ile hukukî ilişki içinde olmayı istememesi durumunda, bu ilişkiyi sözleşmede ve kanunda öngörülen sebeplere dayalı olarak sona erdirebileceğini belirtmektedir. ${ }^{121}$ Ancak bu sonuç üçüncü kişinin menfaatlerini korumak için yeterli değildir. Bu durumda, üçüncü kişinin devreden ile olan hukukî ilişkiye devam etme imkânı elinden alınmaktadır. Üçüncü kişi hukukî ilişkiye kendisi tarafından seçilmeyen bir kişi (devralan) ile devam etme veya ilişkiyi sona erdirme yollarından birini seçmeye zorlanmaktadır.

Açıklanan nedenlerle, İsviçre doktrininde savunulan yeni görüş bu makalede kabul edilmemektedir.

\section{Alman Hukukunun Düzenlemelerinin Açıklanması}

Bu makalede Türk ve İsviçre hukukları için savunulan görüş, Alman hukukunun konu ile ilgili düzenlemeleri ile büyük ölçüde örtüşmektedir. Bu durum, Alman kanun koyucusu tarafından devredenin, devralanın ve üçüncü kişinin menfaatleri arasında bu makalede savunulana benzer bir denge tesis edildiğini göstermektedir.

Türk ve İsviçre hukuklarında zilyetliğin havalesine yüklenen işlevi Alman hukukunda 'iade talebinin devri' (Abtretung des Herausgabeanspruchs) yerine getirmektedir. ${ }^{122}$ Alman Medenî Kanunu’nun $\S 931$ hükmüne göre, üçüncü kişi taşınırın zilyedi ise, malik iade talebinin devri yoluyla taşınır mülkiyetini

120 Ernst (n 5) para 21. Ayrıca bkz Stark ve Lindenmann (n 5) Art 924 para 37. Türk ve İsviçre doktrininde hâkim olan görüşün savunulmuş olduğu bu eserde, üçüncü kişinin devredenle olan borç ilişkisinden doğan şahsî hakları devralana karşı ileri sürebilmesinin sadece (kira sözleşmesine dair düzenlemedeki gibi) devralanın borç ilişkisinde devredenin yerini alması hâlinde mümkün olduğu belirtilmektedir.

121 Ernst (n 5) para 10; Happel (n 5) 67.

122 Eitel (n 32) 77. Alman Medenî Kanunu'nda düzenlenmemiş olmakla beraber, Alman doktrininde 'zilyetliğin havalesi' (Besitzanweisung) adı verilen bir işlem yapılması da kabul edilmektedir. Ancak, bu işlem, Türk ve İsviçre hukuklarında düzenlenen zilyetliğin havalesinden farklıdır. Devredenin üçüncü kişiye yönelik irade beyanı ('havalesi') üzerine, üçüncü kişi devralan için zilyetlik aracısı olma iradesini devralana beyan eder ve devralan da zilyet olma iradesine sahip olursa, devralan dolaylı zilyetlik kazanmış olmaktadır. Bu konuda bkz Wieling (n 18) 455-56. Alman doktrininde kabul edilen zilyetliğin havalesi, İngiliz hukukundaki 'attornment' işlemine tekabül etmektedir. Bu yönde Andreas Rahmatian, 'A Comparison of German Moveable Property Law and English Personal Property Law' (2008) 3 J Comp L 197, 209 dn 108. Alman Medenî Kanunu'nda düzenlenen 'iade talebinin devri' (Abtretung des Herausgabeanspruchs), üçüncü kişinin rızası ve bilgisi olmaksızın devreden ile devralan arasında yapılan bir işlem olması nedeniyle, Türk ve İsviçre hukuklarında düzenlenen zilyetliğin havalesine benzer bir işleve sahiptir. 
nakledilebilir. ${ }^{123}$ Taşınır mülkiyetinin bu yolla nakli durumunda, $§ 986$ hükmünün 2. fikrası uyarınca, taşınırın zilyedi olan üçüncü kişi, devredenin iade talebine karşı ileri sürmesi mümkün olan bütün savunmaları devralana karşı da ileri sürebilir. $\mathrm{Bu}$ düzenleme, borç ilişkisinin nisbîliğine getirilen bir istisna olarak kabul edilmektedir. ${ }^{124}$ Söz konusu hüküm, taşınır mülkiyetinin devrinde teslim ilkesine (Traditionsprinzip) getirilen istisnanın üçüncü kişinin hukukî durumunu kötüleştirmemesi amacına hizmet etmektedir. ${ }^{125} \S 986$ hükmünün 2. fikrası, sadece savunmaların (devralana karşı da ileri sürülebilecek şekilde) 'uzatılması' (Einwandserstreckung) sonucunu doğurmaktadır; devralanın üçüncü kişi ile devreden arasındaki borç ilişkisinde devredenin yerine geçmesine yol açmamaktadır. ${ }^{126} \mathrm{Bu}$ açıdan, kira sözleşmesinin kurulmasından ve kiralananın kiracıya tesliminden sonra kiralananın devrine dair $\S 571$ hükmünden farklıdır. ${ }^{127}$

Alman Medenî Kanunu'nun § 986 hükmünün 2. fikrası, birkaç açıdan Türk ve İsviçre hukuku için bu makalede savunulan görüş ile aynı yöndedir. Söz konusu hüküm sadece taşınırlar için öngörülmüştür; taşınmazlarda uygulanmamaktadır. ${ }^{128}$ Ayrıca, bu hüküm, taşınıra üçüncü kişinin zilyet olması ve üçüncü kişinin rızası olmaksızın taşınırın mülkiyetinin devri durumunda uygulanmaktadır. ${ }^{129}$ Alman doktrininde üçüncü kişinin bu hükme dayalı olarak şahsî (nisbî) hakkından kaynaklanan savunmaları devralana karşı ileri sürebileceği açıkça kabul edilmektedir. ${ }^{130}$ Son olarak, söz konusu hükmün üçüncü kişi ile devreden arasındaki borç ilişkisinde taraf değişikliğine yol açmadiğ belirtilmektedir. $^{131}$

Taşınmazlar açısından Alman Medenî Kanunu'nun kira sözleşmelerine dair düzenlemeleri olan $\S 566^{132}$ ve $\S 578^{133}$ hükümleri devreye girmektedir. Bu hükümlere

123 Taşınır mülkiyetinin bu yolla nakli için, devredenin taşınırın dolaylı zilyedi olması şart değildir. Dolayısıyla, Türk ve İsviçre hukuklarından farklı olarak, Alman hukukunda çalınan veya kaybolan bir taşınırın mülkiyetinin devri mümkündür. Eğer devreden taşınırın dolaylı zilyedi ise, Alman Medenî Kanunu'nun $§ 870$ hükmüne göre, iade talebinin devri ile dolaylı zilyetlik de devralana kazandırılmıș olacaktır.

124 Karl-Heinz Gursky, J. von Staudingers Kommentar zum Bürgerlichen Gesetzbuch mit Einführungsgesetz und Nebengesetzen, Buch 3: Sachenrecht, §§ 985-1011 (Eigentum 3) (Sellier - de Gruyter 2013) §986 para 49.

125 Gursky (n 124) § 986 para 49.

126 Gursky (n 124) § 986 para 49; Waltermann (n 1) 523.

127 Waltermann (n 1) 523.

128 Christian Baldus, ‘§ 986', Münchener Kommentar zum Bürgerlichen Gesetzbuch, Band 8: Sachenrecht (8. Bas1, CH Beck) para 6 ve 71; Gursky (n 124) §986 para 59.

129 Hükümde sadece taşınır mülkiyetinin 'iade talebinin devri' yoluyla nakledilmesinden söz edilmektedir. Ancak, Alman doktrininde, taşınıra zilyet olan üçüncü kişinin rızası olmaksızın mülkiyetin devrinin diğer hâllerinde de $\S 986$ hükmünün 2. fikrasının uygulanması kabul edilmektedir. Mesela, dolaylı zilyet olan devredenin hükmen teslim yoluyla devralana dolaylı zilyetlik kazandırması veya kısa elden teslim yoluyla devralanın zilyetlik sıfatını değiştirmesi böyle durumlar olarak kabul edilmektedir. Bu yönde Baldus (n 128) para 70; Gursky (n 124) § 986 para 55; Waltermann (n 1) 530; Weimar (n 87) 365.

130 Baldus (n 128) para 6 ve 68; Gursky (n 124) § 986 para 49.

131 Gursky (n 124) § 986 para 49; Waltermann (n 1) 523; Weimar (n 87) 364.

132 Türk Borçlar Kanunu'nun 310. maddesinin muadili sayılabilecek olan bu hüküm sadece konutlara (Wohnraum) uygulanmaktadır. Karavan konut olarak kabul edilmemektedir. Ancak, zemin ile daha kuvvetli bağlantısı olan (konteyner gibi) taşınırların konut teşkil edebileceği kabul edilmektedir. Bu yönde Hans Jürgen Bieber, '§ 549', Münchener Kommentar zum Bürgerlichen Gesetzbuch, Band 5: Schuldrecht - Besonderer Teil II (8. Bas1, CH Beck 2020) para 3.

133 Konut teşkil etmeyen taşınmazlara $\S 566$ hükmünün uygulanması $§ 578$ hükmünde yapılan yollama ile öngörülmüştür. 
göre, kiraya verilen konutun ( $(566)$ veya konut teşkil etmeyen taşınmazın ( $(578)$ kiracıya tesliminden sonra, kiraya veren kiralananın mülkiyetini devrederse, devralan kira sözleşmesinin tarafı olur. Kira sözleşmesine dair bu hükümler - Türk Borçlar Kanunu'nun 310. maddesinden ve İsviçre Borçlar Kanunu'nun 261. maddesinden farklı olarak - konut teşkil etmeyen taşınırlara uygulanmamaktadır. Konut teşkil etmeyen taşınırların mülkiyetinin 'iade talebinin devri' yoluyla nakli hâlinde üçüncü kişinin menfaatlerinin korunması için $\S 986$ hükmünün 2. fikrası yeterli görülmektedir. ${ }^{134} \mathrm{Bu}$ makalede de, Türk Borçlar Kanunu'nun 310. maddesinin ve İsviçre Borçlar Kanunu'nun 261. maddesinin konut veya çatılı işyeri teşkil etmeyen taşınırlara uygulanan hükümler olarak öngörülmesi eleştirilmiştir.

\section{Sonuç}

Bu makalede savunulan görüş, Türk ve İsviçre doktrinlerinde hâkim olan görüşten birçok açıdan ayrılmaktadır. Makalede kabul edilen görüşş şu şekilde özetlenebilir:

Türk Medenî Kanunu'nun 979. maddesinin 3. fikrasına göre, üçüncü kişi özel bir hukukî ilişkiye dayalı olarak taşınıra zilyetse ve taşınırın dolaylı zilyedi (devreden) zilyetliğin havalesi yoluyla başka bir kişiye (devralana) dolaylı zilyetlik ve aynî hak kazandırırsa, üçüncü kişi ister aynî hak ister devredene karşı ileri sürülebilen şahsî hak sahibi olsun, kural olarak hakkını devralana karşı ileri sürerek taşınırı iadeden kaçınabilir. Bu durumda, üçüncü kişi ile devreden arasındaki ilişkide devredenin yerini devralanın alması söz konusu değildir. Hukukî iliş̧i üçüncü kişi ile devreden arasında kalmaktadır; üçüncü kişi kanunun özel hükmü sayesinde bu ilişkiden doğan hakkını (şahsî hak olsa bile) ilişkinin tarafı olmayan devralana karşı da ileri sürerek iadeden kaçınabilmektedir.

Taşınırlara uygulanan bu kuralın iki istisnası bulunmaktadır. İlk olarak, taşınır üzerinde aynî hak kazanılması için taşınırın zilyetliğinin devrinin şart olmadığı hâllerde bu kural uygulanmayacaktır. İkinci olarak, üçüncü kişinin taşınıra zilyet olmasına dayanak teşkil eden özel hukukî ilişki devreden ile onun arasındaki kira sözleşmesinden doğmuşsa, Türk Borçlar Kanunu'nun 310. ve 311. maddeleri uygulanacak ve Türk Medenî Kanunu'nun 979. maddesinin 3. fikrasını devre dışı birakacaktır. Bu durumda, devreden (kiraya veren) tarafindan devralana kiralanan taşınırın mülkiyeti devredilir veya taşınır üzerinde sınırlı aynî hak kazandırılırsa, üçüncü kişi (kiracı) ile devreden (kiraya veren) arasındaki hukukî ilişkide (kira sözleşmesinde) devredenin yerini kanunen devralan alacaktır. Üçüncü kişi (kirac1), bu durumda da kira sözleşmesinden doğan alacak hakkını devralana karşı ileri sürebilecek ve böylece kiralanan taşınırı iadeden kaçınabilecektir. Ancak, Türk Medenî Kanunu'nun 979. maddesinin 3. fikrasından farklı olarak, kira sözleşmesinin

134 Beetschen (n 42) 15. Yazara göre, Alman hukukunda kiralanan taşınırın devri durumunda $\S 98 \overline{6 \text { hükmünün 2. fikrası ile }}$ kiracıya tam bir koruma sağlandığından kiralananın devrine dair düzenlemenin taşınırları kapsamasına gerek görülmemiştir. 
tarafı değişmiş olduğundan kiracıya karşı hak sahibi ve borçlu olan kişi kiracının iradesi hilafına değişmiş olmaktadır. Türk Medenî Kanunu'nun 979. maddesinin 3. fikrasının bu makalede savunulan şekilde yorumlanması durumunda, konut veya çatılı işyeri teşkil etmeyen taşınır kiralarında kiracının korunması için gerekli olmayan bu düzenleme, kiracının irade serbestîsine ölçüsüz bir müdahale teşkil etmektedir.

Üçüncü kişinin özel bir hukukî ilişkiye dayalı olarak zilyedi olduğu eşyanın taşınmaz olması hâlinde, devreden tarafından devralana aynî hak ve zilyetliğin havalesi yoluyla dolaylı zilyetlik kazandırılmışsa, Türk Medenî Kanunu'nun 979. maddesinin 3. fikrası uygulanmayacaktır. Dolayısıyla, üçüncü kişi, sadece taşınmaz üzerinde aynî hak sahibi ise, bu hakkını (mutlak hak olması nedeniyle) devralana karşı ileri sürebilecektir. Üçüncü kişi devreden ile arasındaki ilişkiden doğan şahsî (nisbî) hakkını ise devralana karşı ileri sürerek taşınmazı tahliyeden kaçınamayacaktır. Ancak, söz konusu ilişkinin kira sözleşmesinden doğması durumunda, Türk Borçlar Kanunu'nun 310. ve 311. maddeleri devreye girer ve üçüncü kişi ile olan ilişkide devredenin yerini devralan alır. Bu hâlde, üçüncü kişi (kirac1), kira sözleşmesinden doğan şahsî (nisbî) hakkını bu sözleşmenin yeni tarafı olan devralana karşı ileri sürebilecek ve kira sözleşmesi sona erdirilmedikçe kiralanan taşınmazı tahliyeden kaçınabilecektir.

\footnotetext{
Hakem Değerlendirmesi: Dış bağımsız.

Çıkar Çatışması: Yazar çıkar çatışması bildirmemiştir.

Finansal Destek: Yazar bu çalışma için finansal destek almadığını beyan etmiştir.

Teşekkür: Koç Üniversitesi Medenî Hukuk Ana Bilim Dalı Öğretim Üyesi Dr. Işık Önay’a makalenin taslak hâlini okuması ve değerlendirmeleri paylaşması için teşekkür ederim.

Peer-review: Externally peer-reviewed.

Conflict of Interest: The author has no conflict of interest to declare.

Grant Support: The author declared that this study has received no financial support.

Acknowledgements: I would like to thank Dr. Işı Önay, Assistant Professor of Civil Law at Koç University, for reading the draft of the article and sharing his comments.
} 


\section{Bibliyografya/Bibliography}

Acar F, Kira Hukuku Şerhi (3. Bas1, Beta 2016).

Akipek JG ve Akıntürk T, Eşya Hukuku (Beta 2009).

Altınok Ormancı P, ‘Kira Sözleşmesinin Kurulmasından Sonra Kiralananın El Değiştirmesi: "Satım Kirayı Bozmaz” İlkesinin Sonuçları' (2013) 12 İstanbul Ticaret Üniversitesi Sosyal Bilimler Dergisi 125-141.

Arnet R, 'Art. 641', Breitschmid P ve Jungo A (edr), Handkommentar zum Schweizer Privatrecht, Sachenrecht (3. Bas1, Schulthess 2016).

Arnet R ve Eitel P, ‘Art. 920', Breitschmid P ve Jungo A (edr), Handkommentar zum Schweizer Privatrecht, Sachenrecht (3. Bas1, Schulthess 2016).

Aybay A ve Hatemi H, Eşya Hukuku (Vedat 2009).

Baldus C, ‘§ 986’, Münchener Kommentar zum Bürgerlichen Gesetzbuch, Band 8: Sachenrecht (8. Bas1, CH Beck).

Başoğlu B, Mülkiyeti Saklı Tutma Anlaşması (Vedat 2019).

Baur JF ve Stürner R, Sachenrecht (18. Bas1, CH Beck 2009).

Beetschen R, Der Grundsatz 'Kauf bricht Miete'im schweizerischen Recht (Effingerhof 1925).

Bieber HJ, '§ 549', Münchener Kommentar zum Bürgerlichen Gesetzbuch, Band 5: Schuldrecht Besonderer Teil II (8. Bas1, CH Beck 2020).

Bucher E, Obligationenrecht Besonderer Teil (3. Bas1, Schulthess 1988).

Canaris CW, 'Die Verdinglichung obligatorischer Rechte', Jacobs HH ve diğerleri (edr), Festschrift für Werner Flume zum 70. Geburtstag (Verlag Dr. Otto Schmidt KG 1978) 371-427.

Eitel P, 'Bricht Kauf Miete und Leihe bei Fahrnis?', Wiegand W, Koller T ve Walter HP (edr), Tradition mit Weitsicht - Festschrift für Eugen Bucher zum 80. Geburtstag (Stämpfli 2009) 69-80.

Ergüne MS, Taşııır Mülkiyeti (On İki Levha 2017).

Ernst W, 'Art. 924 ZGB', Honsell H, Vogt NP ve Geiser T (edr), Basler Kommentar-Zivilgesetzbuch II (5. Bas1, Helbing Lichtenhahn 2015).

Ertaş Ş, Eşya Hukuku (13. Bası, Barış 2017).

Esener T ve Güven K, Eşya Hukuku (7. Bası, Yetkin 2017).

Fuchs N, Die Besitzesschutzklagen nach Art. 927 ff. ZGB (Dike 2018).

Gursky KH, J. von Staudingers Kommentar zum Bürgerlichen Gesetzbuch mit Einführungsgesetz und Nebengesetzen, Buch 3: Sachenrecht, §§ 985-1011 (Eigentum 3) (Sellier - de Gruyter 2013).

Gümüş MA, Yeni 6098 Sayll Türk Borçlar Kanunu'na Göre Kira Sözleşmesi (Vedat 2011).

Gürsoy KT, Eren F ve Cansel E, Türk Eşya Hukuku (2. Bası, Ankara Üniversitesi Hukuk Fakültesi Yayınlar1 1984).

Happel M, Die Besitzessurrogate im schweizerischen Sachenrecht (Helbing Lichtenhahn 2012).

Hatemi H, Eşya Hukuku (On İki Levha 2020).

Hatemi H, Serozan R ve Arpacı A, Eşya Hukuku (Filiz 1991).

Häublein M, '§ 566 BGB', Münchener Kommentar zum Bürgerlichen Gesetzbuch, Band 5: Schuldrecht - Besonderer Teil II (8. Bas1, CH Beck 2020).

Hedinger MP, System des Besitzesrechts (Stämpfli 1985).

Higi P ve Wildisen C, Zürcher Kommentar, Obligationenrecht, Vorbemerkungen zum 9. Titel, Art. 253-265 OR (5. Bas1, Schulthess 2019). 
Homberger A, Kommentar zum Schweizerischen Gesetzbuch, Band IV: Das Sachenrecht, Dritte Abteilung: Besitz und Grundbuch (2. Bas1, Schulthess 1938).

Huguenin C, Obligationenrecht Allgemeiner und Besonderer Teil (2. Bas1, Schulthess 2014).

Hulliger U ve Heinrich P, 'Art. 260-261a', Müller-Chen M ve Huguenin C (edr), Handkommentar zum Schweizer Privatrecht, Vertragsverhältnisse Teil 1: Innominatkontrakte, Kauf, Tausch, Schenkung, Miete, Leihe (3. Bas1, Schulthess 2016).

Hürlimann-Kaup B, Grundfragen des Zusammenwirkens von Miete und Sachenrecht (Schulthess 2008).

İnceoğlu M, Kira Hukuku (On İki Levha 2014).

Kocayusufpaşaoğlu N, Borçlar Hukukuna Giriş - Hukukî Işlem - Sözleşme (4. Bası, Filiz 2008).

Nomer HN, Beklenen Haklar Üzerindeki Tasarrufların Hukukî Sonuçlarl (Beta 2002).

Nomer HN ve Ergüne MS, Eşya Hukuku (7. Bası, On İki Levha 2019).

Oğuzman MK, Seliçi Ö ve Oktay-Özdemir S, Eşya Hukuku (22. Bası, Filiz 2020).

Ostertag F, Kommentar zum Schweizerischen Zivilgesetzbuch, Band IV: Sachenrecht, III. Abteilung: Art. 919-977 (2. Bas1, Stämpfli 1917).

Öktem Çevik S, Kira Sözleşmesine Etkisi Bakımından Kiralananın Devri ve Sinırl Ayni Hakka Konu Olması (On İki Levha 2016).

Özen B, Haksız Zilyetlikte İade (Beta 2003).

Özen B, ‘Kira Konusunun Devri’ (2010) 16/1-2 MÜHF - HAD 137-179.

Rahmatian A, 'A Comparison of German Moveable Property Law and English Personal Property Law’ (2008) 3 J Comp L 197.

Reber M ve Hurni C (edr), Berner Kommentar, Kommentar zum Schweizerischen Privatrecht, Materialien zum Zivilgesetzbuch, Die Erläuterungen von Eugen Huber, Band II (Stämpfli 2007).

Schmid J ve Hürlimann-Kaup B, Sachenrecht (5. Bas1, Schulthess 2017).

Schöbi F, Der Besitzesschutz (Stämpfli 1987).

Serozan R, Eşya Hukuku I (3. Bası, Filiz 2014).

Sirmen AL, Eşya Hukuku (8. Bas1, Yetkin 2020).

Stark EW, Kommentar zum schweizerischen Privatrecht, Band IV: Das Sachenrecht, 3. Abteilung: Besitz und Grundbuch, 1. Teilband: Der Besitz, Art. 919-941 ZGB (3. Bas1, Bern 2001).

Stark EW, 'Art. 924 ZGB', Honsell H, Vogt NP ve Geiser T (edr), Basler Kommentar Zivilgesetzbuch II (2. Bas1, Helbing Lichtenhahn 2003).

Stark EW ve Lindenmann B, Berner Kommentar, Kommentar zum Schweizerischen Privatrecht, Der Besitz, Art. 919-941 ZGB (4. Bası, Stämpfli 2016).

Steinauer PH, Les droits réels, vol 1 (5. Bas1, Stämpfli 2012).

Sutter-Somm T, Schweizerisches Privatrecht, Band V/1: Eigentum/Besitz (2. Bas1, Helbing Lichtenhahn 2014).

Tekinay SS ve diğerleri, Tekinay Eşya Hukuku, Cilt I (5. Bası, Filiz 1989).

Tuor P ve diğerleri, Das Schweizerische Zivilgesetzbuch (13. Bas1, Schulthess 2009).

Ünal M ve Başpınar V, Şekli Eşya Hukuku (10. Bası, Savaş 2018).

Vardar Hamamcıoğlu G, Medenî Hukuk’ta Tasarruf İşlemi Kavramı (On İki Levha 2014). 
Waltermann R, ‘§ 986 Abs. 2 BGB als Ausdruck einer Verdinglichung schuldrechtlicher Rechtspositionen durch das Gesetz? - Zur Rechtsstellung des schuldrechtlich berechtigten Besitzers' [1993] JURA 521-532.

Weber R, 'Art. 261', Honsell H, Vogt NPve Wiegand W (edr), Basler Kommentar-Obligationenrecht I (6. Bas1, Schulthess 2015).

Weber R, 'Art. 261a', Honsell H, Vogt NP ve Wiegand W (edr), Basler Kommentar Obligationenrecht I (6. Bas1, Schulthess 2015).

Weimar W, 'Die Erhaltungsfunktion des Besitzes gem. § 986 Abs. 2 BGB' [1982] JR 364-365.

Westermann HP, Gursky KH ve Eickmann D, Sachenrecht (8. Bas1, CF Müller 2011).

Wiegand W, 'Art. 641', Honsell H, Vogt NP ve Geiser T (edr), Basler Kommentar-Zivilgesetzbuch II (5. Bas1, Helbing Lichtenhahn 2015).

Wieling H, 'Voraussetzungen, Übertragung und Schutz des mittelbaren Besitzes' (1984) 184 AcP 439-464.

Zycha A, 'Eigentumsverfolgung und Verkehrsschutz bei Fahrnis nach dem Schweizerischen Civilgesetzentwurfe' (1903) 22 ZSR 74-150. 
